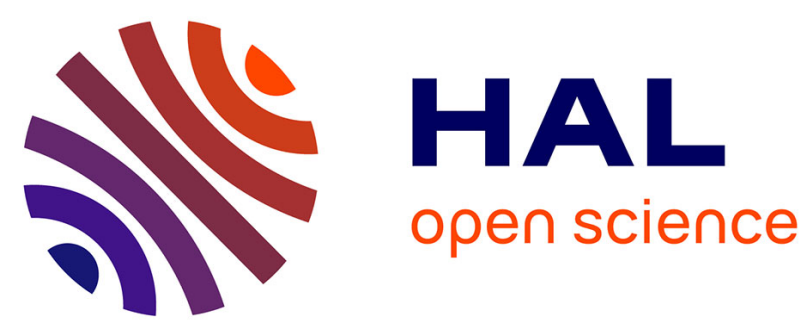

\title{
Isoxazole-Derived Aroylhydrazones and Their Dinuclear Copper(II) Complexes Show Antiproliferative Activity on Breast Cancer Cells with a Potentially Alternative Mechanism Of Action
}

Jesica Paola Rada, Jéremy Forté, Geoffrey Gontard, Vincent Corce, Michèle Salmain, Nicolas Rey

\section{To cite this version:}

Jesica Paola Rada, Jéremy Forté, Geoffrey Gontard, Vincent Corce, Michèle Salmain, et al.. IsoxazoleDerived Aroylhydrazones and Their Dinuclear Copper(II) Complexes Show Antiproliferative Activity on Breast Cancer Cells with a Potentially Alternative Mechanism Of Action. ChemBioChem, 2020, 21 (17), pp.2474-2486. 10.1002/cbic.202000122 . hal-02749888

\section{HAL Id: hal-02749888 \\ https://hal.sorbonne-universite.fr/hal-02749888}

Submitted on 7 Dec 2020

HAL is a multi-disciplinary open access archive for the deposit and dissemination of scientific research documents, whether they are published or not. The documents may come from teaching and research institutions in France or abroad, or from public or private research centers.
L'archive ouverte pluridisciplinaire HAL, est destinée au dépôt et à la diffusion de documents scientifiques de niveau recherche, publiés ou non, émanant des établissements d'enseignement et de recherche français ou étrangers, des laboratoires publics ou privés. 


\title{
Isoxazole-derived aroylhydrazones and their dinuclear copper(II) complexes show antiproliferative activity on breast cancer cells with a potentially alternative mechanism of action
}

\author{
Jesica Paola Rada, ${ }^{[a]}$ Jéremy Fortée, ${ }^{[b]}$ Geoffrey Gontard,${ }^{[b]}$ Vincent Corcé,${ }^{*[b]}$ Michèle Salmain ${ }^{[b]}$ and \\ Nicolás A. Rey ${ }^{\star[a]}$ \\ [a] Dr. J. Rada, 0000-0003-4344-2469, Dr. N. A. Rey, 0000-0002-0624-7560 \\ LABSO-Bio Laboratory, Department of Chemistry \\ Pontifical Catholic University of Rio de Janeiro \\ 225 Rua Marquês de São Vicente (Brazil) \\ E-mail: nicoarey@puc-rio.br \\ [b] J. Forté, 0000-0002-9363-4162, G. Gontard, 0000-0002-4099-5423, Dr. V. Corcé, 0000-0003-2481-7608, Dr. M. Salmain, 0000-0003-3039-5659 \\ Institut Parisien de Chimie Moléculaire (IPCM) \\ Sorbonne Université, CNRS \\ 4 place Jussieu, 75005 Paris (France) \\ E-mail: vincent.corce@sorbonne-universite.fr
}

Supporting information and the ORCID identification number(s) for the author(s) of this article can be found under

\begin{abstract}
This paper reports on the design, synthesis and cytotoxicity studies of two new isoxazole-derived aroylhydrazone ligands and their dinuclear copper(II) complexes. Compounds were fully characterized using various spectroscopic and analytical techniques. The molecular structure of four derivatives was confirmed by X-ray crystallography. The stability of the ligands and the complexes in aqueous medium was monitored spectroscopically. Both the ligands and the complexes were shown to interact with calf thymus DNA (ct-DNA). Additionally, structures containing a phenol pendant arm were significantly more cytotoxic than those carrying a pendant pyridine substituent, reaching submicromolar $\mathrm{IC}_{50}$ values on the triple negative human breast cancer cell line MDA-MB-231. Metal chelation and transchelation ability of the compounds towards $\mathrm{Fe}(\mathrm{II}), \mathrm{Fe}(\mathrm{III})$ and $\mathrm{Zn}$ (II) ions was explored as a possible mechanism of action of these compounds.
\end{abstract}

\section{Introduction}

Copper is an essential metal in the human body involved in many important biological functions. ${ }^{[1]}$ It exhibits singularly interesting redox properties, as well as multiple coordination numbers and geometries. These features make copper complexes remarkably attractive in the discovery of pharmacologically active compounds especially in the field of cancer research, as alternatives to cisplatin, the widely used chemotherapeutic metallodrug. ${ }^{[2]}$

During the last decade, a plethora of mono- and polynuclear copper(II) complexes including various polydentate ligands were synthesized and shown to exhibit both in vitro and in vivo cytotoxic activity, highlighting these complexes as a promising new-generation of anticancer drug candidates. ${ }^{[3-6]}$ Among all the complexes published to date, only a copper complex of the Casiopeínas ${ }^{\circledR}$ family has actually entered Phase I clinical trials. $^{[7]}$

In particular, copper complexation by tridentate aroylhydrazones affords mononuclear and dinuclear complexes via a coordinating $\mathrm{O}, \mathrm{N}, \mathrm{O}-$ system. Complexes of this type showed good to excellent cytotoxic activity on various cancer cell lines whereas the ligands were not toxic. ${ }^{[8-12]}$ Some aroylhydrazone copper(II) complexes were able to induce apoptosis on the HUVEC cellular model, as well as inhibit angiogenesis ${ }^{[13]}$ while other compounds of the same family induced DNA damage and mitochondriamediated cell apoptosis. ${ }^{[14]}$ Mononuclear copper(II) complexes of pyridine containing tetradentate tripodal $\mathrm{N}, \mathrm{N}, \mathrm{N}$ - ligands were also shown to display moderate cytotoxicity on cancer cell lines albeit not much different from that of the ligands alone. ${ }^{[15,16]}$

As part of a research program initially aimed at developing small molecular mimics of dinuclear metalloenzymes such as purple acid phosphatases (PAPs), containing a Fe/M cluster ( $\mathrm{M}=\mathrm{Fe}$, $\mathrm{Zn}$, or $\mathrm{Mn}$ ) or catechol oxidases (COs), which are type-3 copper enzymes, a full series of dinuclear coordination compounds were systematically prepared and studied. ${ }^{[17-24]}{ }^{[24]}$ In the latter case, a symmetrical binucleating Schiff base ligand with a central phenol group mimicking the coordination sphere of the two copper ions in the enzyme was introduced. Not only the $\mu$ hydroxo dicopper complex showed oxidase properties but it also catalyzed the cleavage of DNA through an hydrolytic pathway. ${ }^{[25,26]}$ This complex also presented moderate cytotoxic activity on chronic myelogenous leukemia (K562) and small cell lung carcinoma (GLC4) cell lines, likely by interaction with DNA. ${ }^{[25]}$ A related dicopper complex carrying a central phenol group and two triaza crown (1,4,7-tacn) substituents showed the same general behaviour against pancreatic cancer cells. ${ }^{[27]}$ Very recently, we synthesized two novel unsymmetrical binucleating ligands by appending bipodal and hydrazone entities on each side of the central phenol group. Addition of copper(II) perchlorate resulted in the formation of dicopper complexes with both phenoxo and hydroxo groups bridging tightly the copper centres. Not only the complexes, but the free ligands as well, displayed high cytotoxic activity on a board of cancer cell lines. ${ }^{\text {[28] }}$

Herein, we wish to report two new unsymmetrical binucleating ligands; namely, $\mathbf{H}_{3} \mathbf{L} \mathbf{1}$ and $\mathbf{H}_{2} \mathbf{L} 2$, for which an isoxazole group was appended to the aroylhydrazone moiety. Indeed, isoxazoles and hydrazones are very useful pharmacophores and have become popular in the design of potent new drugs, including anticancer drugs. ${ }^{[29,30]}$ The ligands and four dinuclear copper(II) complexes derived from them by reaction with copper 
perchlorate or copper acetate were synthesized and fully characterized. The molecular structures of both ligands and two of the complexes were solved by X-ray diffraction. Their stability in physiological conditions is reported and discussed. The interaction between the ligands / complexes and calf thymus DNA (ct-DNA) was investigated by UV-visible, fluorescence spectroscopies and circular dichroism. The cytotoxic activity of the ligands / complexes was assessed on the triple negative human breast cancer cell line MDA-MB-231 using a classical MTT cell viability assay.

\section{Results and Discussion}

\section{Design, syntheses and characterization of ligands and their} dicopper(II) complexes

Synthesis of $\mathrm{H}_{3} \mathrm{~L} 1$ and $\mathrm{H}_{2} \mathrm{~L} 2$ was carried out by refluxing equimolar amounts of HBPAMFF $^{[31]}$ or BPMAMFF $^{[32]}$ and 5phenylisoxale-3-carbohydrazone (PIH) in methanol (MeOH) / dichloromethane (DCM) (Scheme 1). Colourless crystals of $\mathbf{H}_{3} \mathbf{L 1}$ and $\mathrm{H}_{2} \mathrm{~L} 2$ were obtained by recrystallization in acetonitrile. The isolated ligands were mixed with two equivalents of copper(II) perchlorate in the presence of potassium hydroxide and refluxed in methanol. The percentage of copper(II) and water in the coordination compounds was determined by inductively coupled plasma optical emission spectrometry (ICP-OES) and thermogravimetric analysis (TGA), respectively, and the electrolytic nature of the complexes was estimated by conductivity measurements (see Supporting Information). The ICP analysis indicated that two copper centres are present in both complexes, and molecules of water or DMSO, together with perchlorate ions, filled the coordination spheres of all the metals. It is worth noting that, despite the addition of $\mathrm{KOH}$ to the reaction mixtures, the expected $\mu$-hydroxo bridge was not observed in the final product. The synthesized dinuclear copper(II) complexes were formulated, correspondingly, as $\left[\mathrm{Cu}_{2}\left(\mathrm{~L}^{3-}\right)\left(\mathrm{ClO}_{4}\right)(\mathrm{DMSO})\left(\mathrm{H}_{2} \mathrm{O}\right)\right] \cdot \mathrm{DMSO} \quad$ (1) and $\left[\mathrm{Cu}_{2}\left(\mathrm{HL}^{-}\right)\left(\mathrm{ClO}_{4}\right)\left(\mathrm{H}_{2} \mathrm{O}\right)_{2}\right]\left(\mathrm{ClO}_{4}\right)_{2} \cdot 3 \mathrm{H}_{2} \mathrm{O}$ (3). Ligands were also mixed with two equivalents of copper(II) acetate monohydrate and refluxed in methanol. In this case, according to ICP and TGA analyses, these dinuclear copper(II) complexes were formulated, respectively,

$\left[\mathrm{Cu}_{2}\left(\mu-\mathrm{OOCCH}_{3}\right)\left(\mathrm{L1}^{3-}\right)\left(\mathrm{H}_{2} \mathrm{O}\right)_{2}\right] \cdot 2 \mathrm{H}_{2} \mathrm{O}$

(2) and $\left[\mathrm{Cu}_{2}\left(\mu-\mathrm{OOCCH}_{3}\right)\left(\mathrm{L2}^{2-}\right)\left(\mathrm{OOCCH}_{3}\right)\left(\mathrm{H}_{2} \mathrm{O}\right)\right] \cdot 2 \mathrm{H}_{2} \mathrm{O}$ (4) (Scheme 1). The compounds were isolated in excellent yield and their formulae confirmed by elemental analysis.

Both ligands were characterized by solution NMR spectroscopy. Aroylhydrazone derivatives can exist as two geometric isomers $(E / Z)$ and two tautomeric forms (amide and iminol). According to the NMR analyses (see Table S1 in Supporting Information), we demonstrated that the $E$-amide form is solely observed for $\mathbf{H}_{3} \mathbf{L} \mathbf{1}$ whereas a small proportion (1\%) of the $E$-iminol form was also present in solution for $\mathbf{H}_{2} \mathrm{~L} 2$. Nevertheless, only the primary ( $E$ amide) form will be considered in this work.

The nature of the coordination of copper by $H_{3} L 1$ and $H_{2} L 2$ was examined by IR spectroscopy. The IR spectra of ligands $\mathbf{H}_{3} \mathrm{~L} 1$ (Fig. S8) and $\mathbf{H}_{2} \mathbf{L 2}$ (Fig. S9) exhibit characteristic stretching bands for phenol, as well as for $\mathrm{NH}$ and carbonyl groups from the hydrazone moiety at around $3444-3433 \mathrm{~cm}^{-1}, 3140 \mathrm{~cm}^{-1}$ and $1675 \mathrm{~cm}^{-1}$, respectively. The IR spectra of complexes $1-4$ (Figs. S10-S13) show strong broad bands characteristic for
vO-H from water near $3430 \mathrm{~cm}^{-1}$. The corresponding $\mathrm{vN}-\mathrm{H}$ and $v \mathrm{C}=\mathrm{O}$ aroylhydrazonic bands present in the spectra of $\mathbf{H}_{3} \mathbf{L} \mathbf{1}$ and $\mathbf{H}_{2} \mathrm{L2}$ disappear in the spectra of complexes 1, 2 and 4 suggesting coordination of this group in the iminolate form. Taking into account the elemental analysis and molar conductivity of complex $\mathbf{3}$, the hydrogen from the aroylhydrazone group (-HNCO-) seemed to be conserved in the complex. Furthermore, the stretching phenol $\mathrm{C}-\mathrm{O}$ bands in the spectra of the ligands near $\sim 1235 \mathrm{~cm}^{-1}$ are shifted to $\sim 1285 \mathrm{~cm}^{-1}$ in the spectra of the complexes, suggesting deprotonation and coordination of the pendant arm and central phenol groups. The typical Schiff base azomethine group bands are located near $1610 \mathrm{~cm}^{-1}$ in the IR spectra of both the complexes and ligands, confirming the relative insensitivity of this mode to coordination. Additionally, the IR spectra of complexes $\mathbf{1}$ and $\mathbf{3}$ present strong bands characteristic of coordinated $\mathrm{ClO}_{4}^{-}$, linked to antisymmetric $\mathrm{U}_{3}$ and symmetric $\mathrm{U}_{3}$, and $\mathrm{U}_{4}$ modes. The latter bands are located at 1097, 1022 and $622 \mathrm{~cm}^{-1}$, respectively, in the spectrum of complex 1 , and at 1108,1031 and $625 \mathrm{~cm}^{-1}$ in
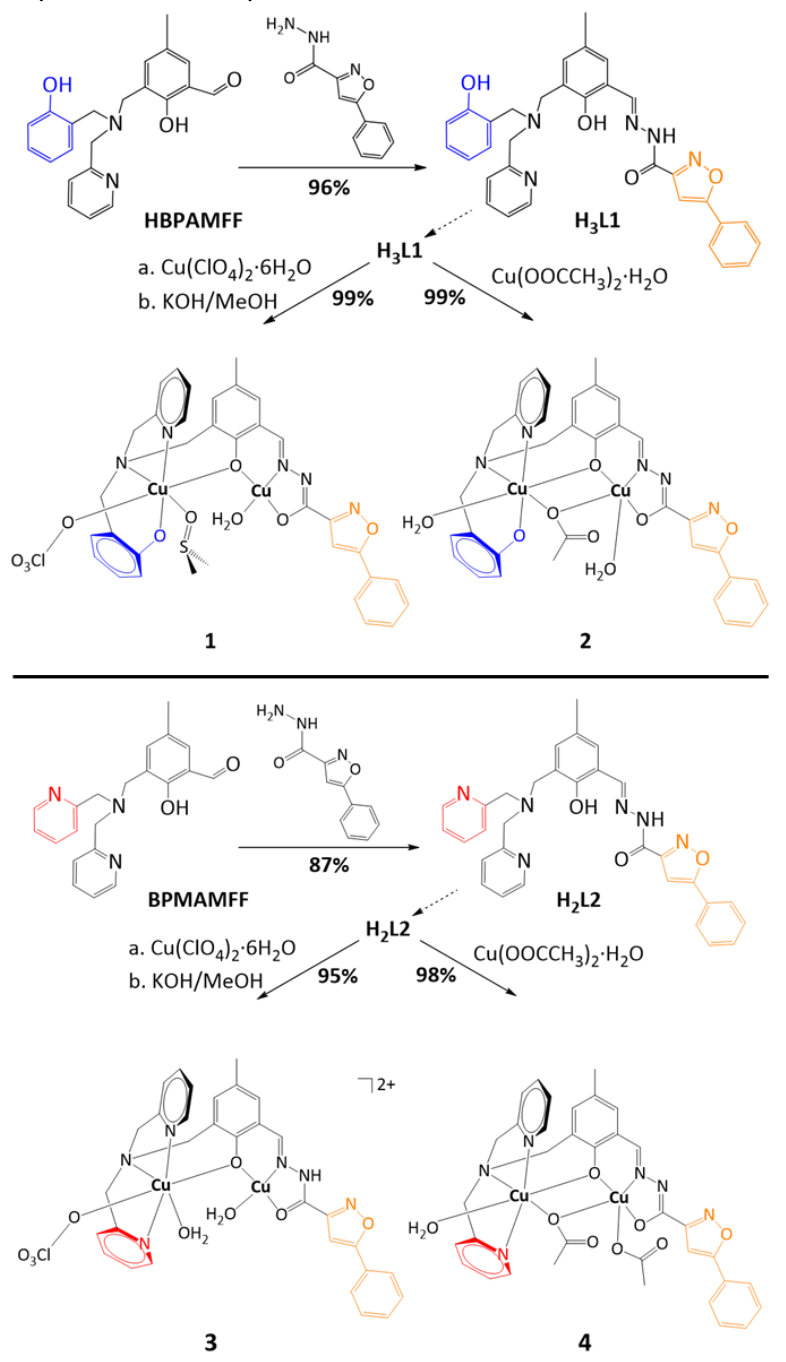

that of complex 3 . The presence of the perchlorate bands confirms the coordination of the perchlorate ion $\left(\mathrm{Cu}-\mathrm{ClO}_{4}\right)$.

Scheme 1. Synthetic routes to ligands $H_{3} L 1$ (top) and $H_{2} L 2$ (bottom) and thei dicopper(II) complexes from perchlorate (1 and $\mathbf{2}$ ) or acetate ( $\mathbf{3}$ and $\mathbf{4})$ salts. 
The electronic spectra of complexes and ligands in $\mathrm{H}_{2} \mathrm{O} / \mathrm{DMSO}$ 9:1 (v/v) showed a pattern of absorption bands in the $230-500$ $\mathrm{nm}$ region (Figs. $\mathrm{S} 14$ and $\mathrm{S} 15$; molar absorptivities in $\mathrm{H}_{2} \mathrm{O}$ /DMSO $9: 1$ in Table S9). In the spectrum of $\mathbf{H}_{3} \mathbf{L} \mathbf{1}$, absorption bands associated to HBPAMFF moiety were located at $343 \mathrm{~nm}$ (broad) and $262 \mathrm{~nm}$ (shoulder). Also, two bands located at 301 and $290 \mathrm{~nm}$, and completely absent in the precursors' spectra, appeared in the $\mathbf{H}_{3} \mathrm{~L} \mathbf{1}$ absorption spectrum (Fig. S14). Consequently, these bands were assigned to the aroylhydrazone moiety.

All four complexes displayed an almost identical absorption profile in the $230-500 \mathrm{~nm}$ region. For instance, in the absorption spectrum of $\mathbf{1}$, the HBPAMFF moiety absorption redshifted from 343 to $392 \mathrm{~nm}$. This change was attributed to the deprotonation of this moiety and coordination of copper ions by the phenolate and pyridine groups. The contribution of $\mathrm{PIH}$, and also HBPAMFF, to the absorption of complex $\mathbf{1}$ appeared as shoulders at 278 and $262 \mathrm{~nm}$. Finally, the aroylhydrazone transitions redshifted to 334 and $318 \mathrm{~nm}$, in agreement with copper ions coordination.

In pure DMSO, the electronic spectra of the complexes present a broad and weak absorption band centred at $676 \mathrm{~nm}(\varepsilon=95$ $\left.\mathrm{M}^{-1} \mathrm{~cm}^{-1}\right)$ for $1,679 \mathrm{~nm}\left(\varepsilon=97 \mathrm{M}^{-1} \mathrm{~cm}^{-1}\right)$ for $2,675 \mathrm{~nm}(\varepsilon=110$ $\left.\mathrm{M}^{-1} \mathrm{~cm}^{-1}\right)$ for 3 , and $672 \mathrm{~nm}\left(\varepsilon=102 \mathrm{M}^{-1} \mathrm{~cm}^{-1}\right)$ for 4 (Fig. S16). These bands are assigned to $d-d$ (ligand field) transitions between the electronic states of the copper centres. ${ }^{[33]}$

\section{X-ray crystal structures}

The ORTEP views of the crystal structures of $\mathrm{H}_{3} \mathrm{~L} 1$ and $\mathrm{H}_{2} \mathrm{~L} 2$ are shown in Figure 2 (crystallographic data and structural refinement parameters can be found in Table S2; geometric parameters for $\mathbf{H}_{3} \mathrm{L1}$ and $\mathbf{H}_{2} \mathrm{~L} 2$ are given in Table S3). The crystal structure of $\mathbf{H}_{3} \mathrm{~L} \mathbf{1}$ is a racemate due to the chiral tertiary N3 centre.

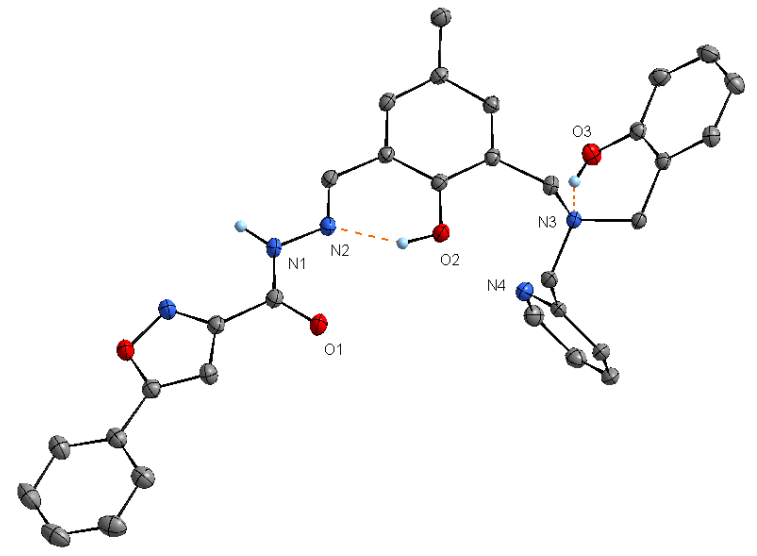



Figure 2. Crystal structures of ligands $\mathrm{H}_{3} \mathrm{L1}$ (Top) and $\mathrm{H}_{2} \mathrm{~L} 2$ (Bottom). Ellipsoids are drawn with $30 \%$ probability. Only hydrogen atoms involved in hydrogen bonds are shown, for the sake of clarity. Intramolecular bonds are depicted in orange dotted lines. For the chiral compound $\mathbf{H}_{3} \mathbf{L} \mathbf{1}$, only one of the enantiomers is represented.

Phenylisoxazole, aroylhydrazone and mesitol groups are in a same plane, with only a small torsion observed between phenylisoxazole and the aroylhydrazone groups Additionally, in both ligands, the heteroatoms $\mathrm{N} 1$ and $\mathrm{O} 2$ are protonated, as well as $\mathrm{O} 3$ from the phenol arm of $\mathbf{H}_{3} \mathrm{~L} 1$. For ligand $\mathbf{H}_{2} \mathrm{~L} 2$, only one intramolecular $\mathrm{H}$-bond was observed, while for $\mathbf{H}_{3} \mathbf{L} \mathbf{1}$, one extra intramolecular hydrogen bond was identified (Figure 2 and Table S4). Therefore, in both cases, the hydrogen atom $\mathrm{H}-\mathrm{O} 2$ (mesitol group) is directed directly towards the $\mathrm{N} 2$ atom (hydrazone moiety) to create a six-membered ring. The supplementary intramolecular $\mathrm{H}$-bond in $\mathrm{H}_{3} \mathrm{~L}$ 1 between $\mathrm{O} 3-\mathrm{H}$ hydrogen and amine N3, creates a six-membered ring as well. Complexes $\mathbf{1}$ and $\mathbf{4}$ were recrystallized, one-to-one, in DMSO and DMF as dark green single crystals. Due to this, in the asymmetric unit of complex $\mathbf{1}$, one DMSO molecule is coordinated to the Cu2 atom. Besides, one additional DMSO appears as uncoordinated solvent. The ORTEP views of the crystal structures of $\mathbf{1}$ and $\mathbf{4}$ derived from ligands $\mathrm{H}_{3} \mathrm{~L} \mathbf{1}$ and $\mathrm{H}_{2} \mathrm{~L} 2$ respectively are shown in Figure 3 (crystallographic data and structural refinement parameters can be found in Table S5 and selected geometric parameters for complexes $\mathbf{1}$ and $\mathbf{4}$ are shown in Table S6).

In the structure of $\mathbf{1}$, Cu1 adopts a slightly distorted square planar geometry with $\mathrm{O} 1$ and N2 (hydrazone group), O2 (bridging phenoxo group from the mesitol moiety) and $\mathrm{O5}$ (water molecule) as donor atoms. The hydrazone group is coordinated in its deprotonated iminolate form, thus confirming the IR spectroscopy findings.

The coordination polyhedron around Cu2 is a heavily axially distorted octahedron. In the equatorial plane, $\mathrm{Cu} 2$ is coordinated by N3 (amine), O3 and N4 (pyridine) atoms from the deprotonated meridional

HBPA [(hydroxybenzyl)(pyridinylmethyl)amine] moiety, as well as to O10 (from a DMSO molecule). In addition, one of the apical positions is occupied by the $\mathrm{O} 2$ atom from the bridging phenoxo group. The oxygen $\mathrm{O} 6$ atom from a perchlorate ion is distanced by 2.704(2) ̊ from Cu2, thus completing the distorted elongated octahedral environment.

On one hand, in the crystal structure of complex 4, Cu1 is in a slightly distorted square pyramidal environment, coordinated in 
the basal plane to $\mathrm{O} 1$ and $\mathrm{N} 2$ atoms from the hydrazone group in its iminolate form, to $\mathrm{O} 2$ of the phenoxo group and to $\mathrm{O} 4$ from a terminal monodentate acetate ligand. The coordination sphere is completed by $\mathrm{O} 6$ atom from the bridging acetate, which occupies the apical position. On the other hand, Cu2 of complex 4 displays a heavily distorted octahedral geometry, whose equatorial plane is constituted by the tertiary amine N3 (from the meridional BPMA moiety), as well as N4 and N5 (the bipyridine methylamine groups of BPMA), and, finally, $\mathrm{O} 6$ atom (from the bridging acetate anion). Additionally, the $\mathrm{O} 2$ atom (bridging phenoxo group) and the 08 atom (from a water molecule) complete the distorted elongated octahedral environment of $\mathrm{Cu} 2$ occupying apical positions.

Complexes $\mathbf{1}$ and $\mathbf{4}$ share some similarities: (i) the isoxazole group was not involved in the copper coordination; (ii) the Cu1Cu2 distances were identical in the two complexes; (iii) the two equatorial planes around $\mathrm{Cu} 1$ and $\mathrm{Cu} 2$ are not in the same plane; and finally, (iv) both complexes presented one dissymmetric bridging phenoxo group.

A dissymmetric bridging interaction provided by only one of the two oxygen atoms of an acetate ligand was also observed for complex 4. Coordination mode of this acetate ligand is monoatomic bridging type $(\mu 2-\eta 2: \eta 0){ }^{[34,35]}$
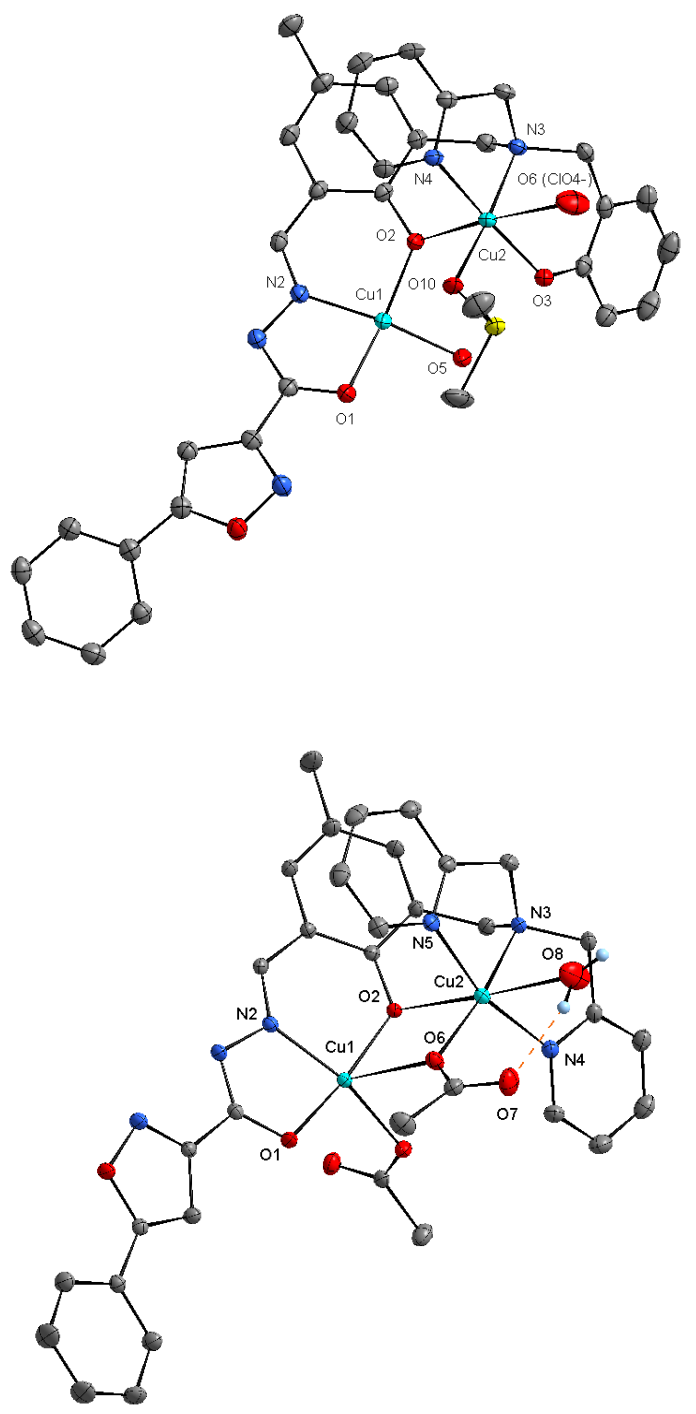

Figure 3. Crystal structures of complex 1 (Top) and complex 4 (Bottom). Ellipsoids are drawn with $30 \%$ probability. Only hydrogen atoms involved in hydrogen bonds are shown for the sake of clarity. Intramolecular bonds are depicted in orange dotted lines. Free water, DMSO or perchlorate counter-ion molecules were omitted for the sake of simplicity. For complex $\mathbf{1}$, only one oxygen atom from the perchlorate ion (O6) and the oxygen atom from coordinated DMSO $(\mathrm{O} 10)$ are shown, for the sake of simplicity. Only one of the enantiomers is represented for this compound. Cu1-Cu2 distances $(\AA)$ : $(\mathbf{1})$ 3.4002(4) and (4) 3.4024(5). Cu1-O2 distances $(\AA)$ : (1) 1.8996(20) and (4) 1.9606(14). Cu2-O2 distances (Å): (1) 2.3051(16) and (4) 2.3801(15).

\section{Stability studies}

Prior to exploring their potential application as anticancer drugs, the stability of complexes $\mathbf{1 - 4}$, first in DMSO then in physiological conditions $\left(37^{\circ} \mathrm{C}\right.$, PBS/DMSO 99:1 pH 7.4), was examined. Absorption spectra of the compounds $(10 \mu \mathrm{M}$ in DMSO) revealed insignificant variations for up to $24 \mathrm{~h}$ at room temperature (Fig. S17). After $24 \mathrm{~h}$, the perchlorate complexes 1 and 3 presented the highest stability in DMSO solution, with residual concentration corresponding to $95 \%$ of the initial concentration $\mathrm{C}_{0}$, while the residual concentration of ligands was $93 \%$ of $\mathrm{C}_{0}$ on average.

In PBS, yet, significant changes were observed in the absorption spectra (Fig. S17). During the first hours ( $1-6 \mathrm{~h}$ and $24 \mathrm{~h}$ ), the spectra of complexes and ligands presented similar behaviour in the experimental conditions tested (Fig. S18). After $24 \mathrm{~h}$, the average concentration of the compounds in the solution was $55 \%$ of $\mathrm{C}_{0}$. This value decreased to $36 \%$ for the complexes after $72 \mathrm{~h}$, and to $12 \%$ and $5 \% \mathrm{C}_{0}$ for ligands $\mathrm{H}_{3} \mathrm{~L} \mathbf{1}$ and $\mathbf{H}_{2} \mathrm{L2}$, respectively. Hydrazones can be hydrolyzed in aqueous solution to carbonyl and hydrazide precursors. ${ }^{[36]}$ The same behaviour was observed when the stability studies were conducted in DMEM. When hydrazones are involved in metal complexation, the hydrolysis process is prevented due to the involvement of the azomethine nitrogen in coordination. Let us notice that the hydrazide precursor PIH displayed a higher molar absorptivity than the ligands and complexes (see Figs. S14 and S15). Therefore, ligand / complex hydrolysis should result in an increase of absorbance in the UV range. Conversely, with time, absorption bands of ligands and complexes presented a global hypochromic effect, ruling out ligands / complexes' hydrolysis and formation of the free PIH precursor. The observed result suggests that precipitation could be the dominant process responsible for the observed hypochromism. On the other hand, in the solid state, both ligands and complexes are stable for months.

\section{ct-DNA interaction studies by absorption and fluorescence spectroscopy and circular dichroism}

The cytotoxic activity of some copper complexes has been previously linked to their interaction with DNA. ${ }^{[11,12,14,37]}$ Therefore, we investigated the in vitro interaction of ligands $\mathbf{H}_{3} \mathbf{L 1}$ and $\mathbf{H}_{2} \mathrm{~L} 2$ and the copper complexes 1-4 with ct-DNA. Absorption and fluorescence spectroscopies were used to determine the binding affinities and to estimate the interaction mode of the compounds with this biopolymer. Significant spectral changes were observed upon addition of ct-DNA (0 $50 \mu \mathrm{M})$ to ligands and complexes $(25 \mu \mathrm{M})$ solutions (Figure 4). Progressive addition of DNA resulted in a hypochromic shift of the absorption bands of $\mathbf{H}_{3} \mathbf{L} \mathbf{1}$ and its copper complexes $\mathbf{1}$ and $\mathbf{2}$ (up to $43 \%$, Column I), especially the hydrazone bands (close to 
$296 \mathrm{~nm}$ in ligands and $315 \mathrm{~nm}$ in complexes). The UV-vis spectrum of $\mathbf{H}_{2} \mathrm{~L} 2$ was less affected by the addition of DNA, whereas the spectrum of $\mathbf{3}$ and $\mathbf{4}$ did not change at all. The decrease in absorbance caused by ct-DNA was accompanied by a slight redshift of the bands. The red shift was more pronounced in the case of the absorption bands associated to the HBPAMFF or BPMAMFF moieties, near $350 \mathrm{~nm}$ for ligands and near $390 \mathrm{~nm}$ for complexes (Table 1).



Figure 4. Absorption spectra of ligands (A) $\mathbf{H}_{3} \mathrm{~L} 1$; (B) $\mathbf{H}_{2} \mathrm{~L} 2$ and complexes (C) 1; (D) 3; (E) 2; and (F) 4 at a $25 \mu \mathrm{M}$ alone or with increasing concentration of ct-DNA (arrow, $0-50 \mu \mathrm{M}$ ) in PBS/DMSO 9:1 at $25^{\circ} \mathrm{C}$. Inset: Plot of $1 / \mathrm{A}_{0}-\mathrm{A}$ versus $1 /[$ ct-DNA] and its linear fit.

The Benesi-Hildebrand equation (eq S1) with modified approach (eq S2) was used to estimate the binding constants $K_{\mathrm{b}}{ }^{[38]}$ The calculated $K_{\mathrm{b}}$ values (Table 1 ) reveal a similar interaction of $\mathrm{H}_{3} \mathrm{~L} 1$ and $\mathrm{H}_{2} \mathrm{~L} 2$ with ct-DNA. The calculated binding constants are of the order of $\sim 10^{1} \mathrm{M}^{-1} / \sim 10^{2} \mathrm{M}^{-1}$ larger than those reported for other hydrazone ligands. ${ }^{[39]}$ Besides, ligands $H_{3} L 1$ and $H_{2} L 2$ showed a higher DNA affinity than our previously reported HBPAMFF-aroylhydrazone ligands containing non-coordinating furan or thiophene groups. ${ }^{[28]}$ Thus the presence of the planar isoxazole fragment clearly increases the affinity for ct-DNA. The $K_{\mathrm{b}}$ constants for 1-4 are comparable to those reported for other copper(II) complexes. ${ }^{[40-42]}$ The calculated $K_{b}$ values for the ligands and complexes were smaller than the binding constant of the conventional DNA intercalator ethidium bromide, EB (in the order of $\left.\sim 10^{5} \mathrm{M}^{-1}\right) \cdot{ }^{[43]}$ Both ligands presented an emission band at $530 \mathrm{~nm}$ for $\mathbf{H}_{3} \mathrm{~L} 1$ and $503 \mathrm{~nm}$ for $\mathbf{H}_{2} \mathrm{~L} 2$ upon excitation at $350 \mathrm{~nm})$. Titration of ligands $(5 \mu \mathrm{M})$ by ct-DNA $(0-120 \mu \mathrm{M})$ resulted in a progressive decrease of the fluorescence intensity without wavelength shift (Fig. 5, A and B).

Fluorescence measurements were corrected from the "inner filter effect" (eq S3) and the Scatchard equation (eq S4) was used to calculate the number of active sites $(n)$ and the binding constant $\left(K_{\mathrm{b} 2}\right) .{ }^{[44]} K_{\mathrm{b} 2}$ of ligand $\mathbf{H}_{3} \mathbf{L} 1$ was ten-fold higher than that of $\mathbf{H}_{2} \mathrm{~L} 2$, and both were much lower than that measured for $E B$ (of the order of $\sim 10^{7} \mathrm{M}^{-1}$ ). ${ }^{[45]}$ The calculated $n$ suggests that one ligand molecule interacts with one nucleobase pair of ct-DNA. Copper(II) complexes did not display fluorescence emission. Therefore, their interaction with DNA was indirectly examined through EB displacement assay. Hence, the fluorescence emission of a mixture of DNA $(10 \mu \mathrm{M})$ and EB $(5 \mu \mathrm{M})$ at $604 \mathrm{~nm}$ was monitored in the presence of increasing concentration of the complexes $(0-50 \mu \mathrm{M}$, Figure $5(\mathrm{C}-\mathrm{F}))$. Emission was shown to decrease in the case of complexes 3 and 4 , up to $96 \%$ on average (Table 1). This was rationalized by the displacement of EB from the EB-DNA caused by the complexes. The binding constants of the complexes to DNA $\left(K_{\text {app }}\right)$ were calculated indirectly from the binding constant of $\mathrm{EB}\left(K_{\mathrm{EB}}=1.0 \times 10^{7} \mathrm{M}^{-1}\right)$, using the equation $K_{\mathrm{EB}} \times[\mathrm{EB}]=K_{\mathrm{app}} \times$ [complex] where [EB] refers to the concentration of $E B$ and [complex] represents the concentration of the complexes when the initial fluorescence emission intensity of EB-DNA system is reduced by $50 \%$.

In brief, $K_{\text {app }}$ values when the complexes displaced $50 \%$ of EB were in the $10^{6} \mathrm{M}^{-1}$, in the decreasing order: complexes $\mathbf{3}>\mathbf{4}>$ $2>1$ (Table 1). The values are comparable to other dinuclear copper(II) complexes. ${ }^{[46]}$

Additionally, using the Stern-Volmer equation (eq S5), the quenching rate constants $\left(K_{\mathrm{q}}\right)$ were calculated taking an average intrinsic lifetime $\left(T_{0}\right)$ of $23 \mathrm{~ns}^{[47]}$ and the suppression-constants $K_{\mathrm{s}}$. $K_{\mathrm{q}}$ values were $2.67 \times 10^{12} \mathrm{M}^{-1} \mathrm{~s}^{-1}, 9.92 \times 10^{12} \mathrm{M}^{-1} \mathrm{~s}^{-1}, 7.49 \times$ $10^{13} \mathrm{M}^{-1} \mathrm{~s}^{-1}, 3.19 \times 10^{13} \mathrm{M}^{-1} \mathrm{~s}^{-1}$ for complexes $\mathbf{1}, \mathbf{2}, \mathbf{3}$ and $\mathbf{4}$ respectively. It must be noted that the calculated quenching rate constants are two to three orders of magnitude higher than the maximum $K_{\mathrm{q}}$ of a pure dynamic quenching mechanism for diffusion-controlled $\left(2.0 \times 10^{10} \mathrm{M}^{-1} \mathrm{~s}^{-1}\right)$.

Table 1. Absorption and fluorescence features of the interaction of ligands $\mathbf{H}_{3} L 1$ and $\mathbf{H}_{2} \mathrm{~L} 2$ and their dicopper(II) complexes 1-4 with ct-DNA.

\begin{tabular}{ccccc}
\hline Comp. & $K_{\mathrm{b}}\left(\times 10^{4} \mathrm{M}^{-1}\right)^{[\mathrm{a}]}$ & $K_{\mathrm{sv}}\left(\mathrm{M}^{-1}\right)$ & $K_{\mathrm{app}}$ or $K_{\mathrm{b} 2}\left(\mathrm{M}^{-1}\right)^{[\mathrm{a}, \mathrm{b}]}$ & $n$ \\
\hline $\mathbf{H}_{3} \mathrm{~L} 1$ & $(4.82 \pm 0.03)$ & $(2.67 \pm 0.01) \times 10^{4}$ & $(1.0 \pm 0.2) \times 10^{2}$ & 0.6 \\
$\mathbf{H}_{2} \mathrm{~L} 2$ & $(4.46 \pm 0.07)$ & $(9.92 \pm 0.01) \times 10^{4}$ & $(1.7 \pm 0.1) \times 10^{1}$ & 0.5 \\
$\mathbf{1}$ & $(4.68 \pm 0.07)$ & $(7.49 \pm 0.06) \times 10^{5}$ & $(7.86 \pm 0.03) \times 10^{5}$ & 1.0 \\
$\mathbf{2}$ & $(4.75 \pm 0.06)$ & $(3.19 \pm 0.02) \times 10^{5}$ & $(1.66 \pm 0.01) \times 10^{6}$ & 1.3
\end{tabular}




\begin{tabular}{lllll}
3 & $(2.11 \pm 0.02)$ & $(2.67 \pm 0.01) \times 10^{4}$ & $(3.23 \pm 0.02) \times 10^{6}$ & 2.0 \\
4 & $(4.43 \pm 0.06)$ & $(9.92 \pm 0.01) \times 10^{4}$ & $(2.69 \pm 0.01) \times 10^{6}$ & 1.8 \\
\hline
\end{tabular}

[a] (mean \pm S.D). [b] $K_{\text {app }}$ (for complex), $K_{\mathrm{b} 2}$ (for ligand).

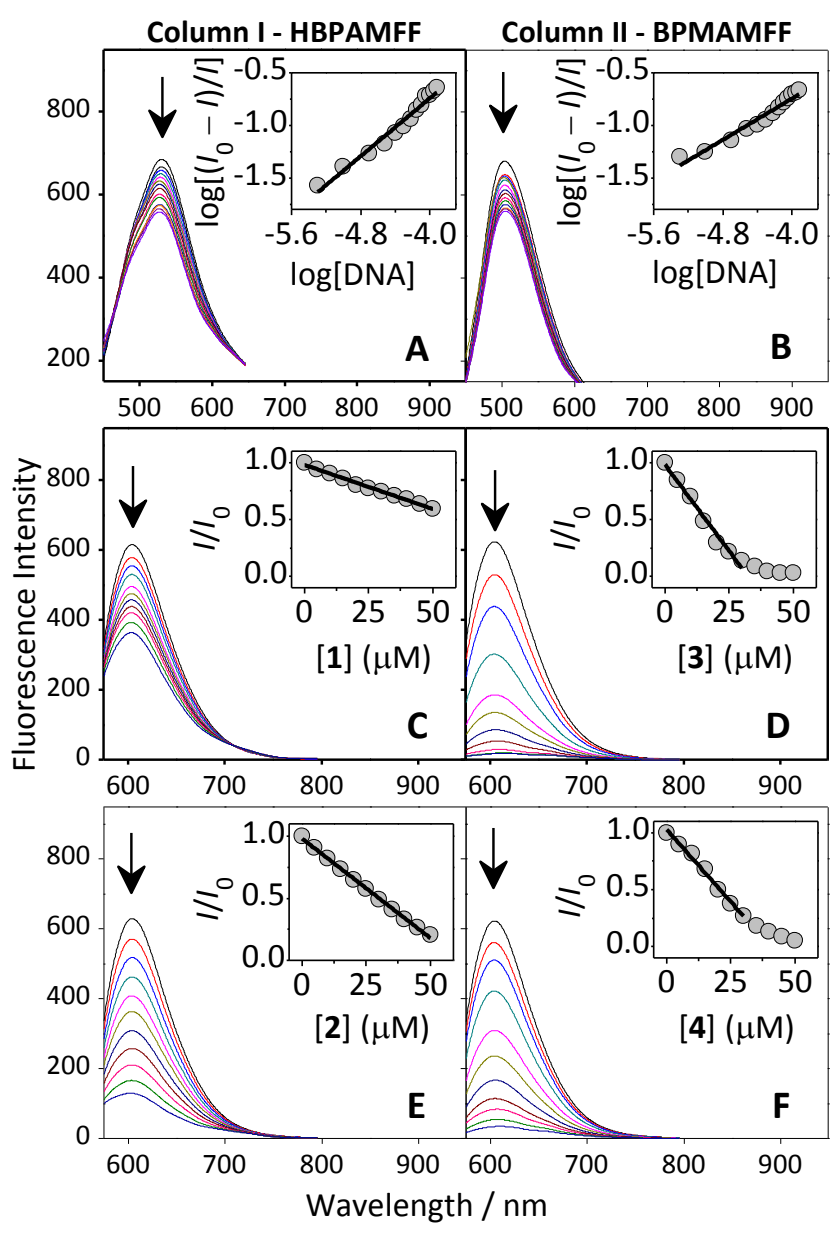

Figure 5. Fluorescence spectra in PBS/DMSO $99: 1$ at $25^{\circ} \mathrm{C}$ of ligands $(\mathrm{A})$ $H_{3} L 1$ and $(B) H_{2} L 2\left(5 \mu M, \lambda_{\text {ex }}=350 \mathrm{~nm}\right)$ alone or in the presence of ct-DNA (arrow, $0-120 \mu \mathrm{M}$ ). Inset: plot of $\log \left[\left(l_{0}-I\right) / /\right.$ versus $\log [\mathrm{ct}-\mathrm{DNA}]$; Fluorescence spectra of ct-DNA $(10 \mu \mathrm{M})$ and EB $\left(5 \mu \mathrm{M}, \lambda_{\text {exc }}=555 \mathrm{~nm}\right)$ alone or in the presence (arrow, $0-50 \mu \mathrm{M}$ ) of complexes (C) 1; (D) 2; (E) 3; and (F) 4. Inset: plot of $I / I_{0}$ versus [complex] and its linear fit.

Then, the found $K_{\mathrm{q}}$ indicate that in the displacement of EB from DNA by the complexes results from a static quenching mechanism. The calculated $K_{\mathrm{s}}$ for the titration of EB-DNA system with the complexes are shown in Table 1. The binding constants (Table 1$)$ of the ligands $\left(K_{\mathrm{b} 2}\right)$ and complexes $\left(K_{\mathrm{app}}\right)$ with ct-DNA obtained through EB displacement assay, reveals a higher affinity of the copper complexes (up to five orders of magnitude) for DNA compared to the ligands. Previous copper(II) complexes mimicking the active site of catechol oxidase exhibited phosphate diester hydrolysis activity, probably involving terminal coordination. ${ }^{[26,48,49]}$ In general, the ability of the complexes to interact with phosphate groups is thus in line with the higher binding constants of the complexes compared to the ligands. Besides, the higher $K_{\text {app }}$ of complex 3 , could be related to the positive charge $(2+)$ of this complex, which interacts more easily than the neutral complexes with the phosphate groups of dsDNA. The number of active sites (eq. S4;
Fig. S19, C-F) was higher for complexes ( $n=1$ or 2 ) than for ligands $(n=0.5)$.

To clarify the binding interaction of both ligands and complexes with ct-DNA, circular dichroism (CD) spectroscopy was applied (Figure 6). Free ct-DNA exhibits two characteristic bands: a positive band at $275 \mathrm{~nm}$ attributed to the base stacking and a negative band at $245 \mathrm{~nm}$ due to the helicity of the right-handed $B$ form of DNA. Interaction of small molecules induces changes in the CD signals of DNA. Intercalation stabilizes the B-DNA, leading to an increase in the intensities of both bands.

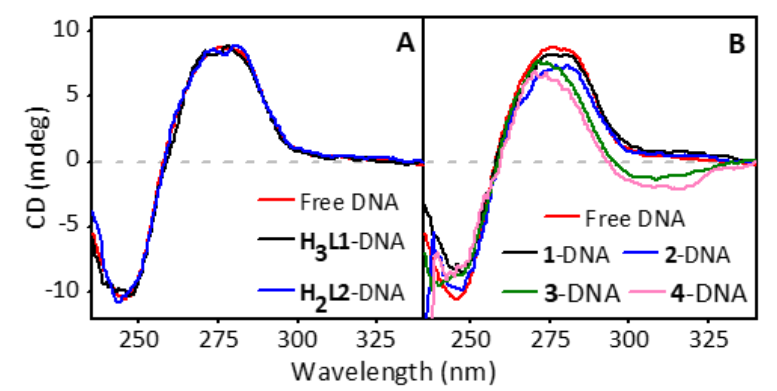

Figure 6. Circular Dichroism spectra: (A) ct-DNA in the presence of $\mathbf{H}_{3} \mathbf{L 1}$ and $\mathrm{H}_{2} \mathrm{L2}$ (B) ct-DNA in the presence of $1,2,3$, and 4. Conditions: [DNA] = [compound] $=50 \mu \mathrm{M}$ in $5 \mathrm{mM}$ Tris- $\mathrm{HCl} / 50 \mathrm{mM} \mathrm{NaCl}$ buffer $5 \%$ DMSO.

On the opposite, electrostatic interaction with DNA results in little or no perturbation of the CD signal. Treatment of ct-DNA with both ligands $H_{3} L 1$ and $H_{2} L 2$ induced no changes in the $C D$ signal, likely owing to electrostatic interaction. For complexes 14, only a small reduction of the negative band was observed. This decrease in the helicity band suggests that all complexes interact with DNA by minor groove binding. Finally, taking into account all the results obtained from both absorption, fluorescence spectroscopy and circular dichroism, the nonintercalative interactions seems to be the only component for the compounds-DNA interaction

\section{In vitro cytotoxic activity}

The investigation of the cytotoxic effect of the ligands and their respective copper(II) complexes is one of the main goals of the current work. We first intended to compare the structurally similar ligands $\mathbf{H}_{3} \mathrm{~L} 1$ and $\mathbf{H}_{2} \mathrm{~L} 2$, only differing by one of their aromatic rings, a phenol for the former and a pyridine for the latter. We also intended to compare dicopper(II) complexes differing by their first coordination sphere obtained by treating the ligands with copper(II) perchlorate hexahydrate (complexes $\mathbf{1}$ and $\mathbf{3}$ ) or copper(II) acetate monohydrate (complexes $\mathbf{3}$ and $\mathbf{4}$ ). We have shown in a previous study that binuclear copper(II) complexes with hydrazonic ligands gave very promising activities on the triple negative breast cancer cell line MDA-MB231. ${ }^{[28]}$ To confirm this trend, cytotoxicity evaluations in the present studies were carried out only on this cancer cell line. Cells were incubated with medium containing different concentrations of each ligand or copper(II) complex during a period of $72 \mathrm{~h}$. Cytotoxicity was evaluated as the ability of the compounds to inhibit cell growth using the MTT assay. The 
concentration dependence on cell viability can be observed in Figure 7 and S20.

Compounds based on the phenol-pyridine precursor HBPAMFF exhibited considerably high cytotoxicity on MDA-MB-231 cells. The $\mathrm{IC}_{50}$ of compounds $\mathbf{H}_{3} \mathbf{L} \mathbf{1}, \mathbf{1}$ and $\mathbf{2}$ were in the submicromolar range, while BPMAMFF-derived compounds displayed a micromolar potency towards the tested cell line (Table 2).


Figure 7. Dose-dependent effect expressed as the percentage of relative viability of MDA-MB-231 cells measured by the MTT assay for $(A) \mathbf{H}_{3} \mathrm{L1}$; (B) $\mathrm{H}_{2} \mathrm{L2}$; (C) 1; (D) 2; (E) 3; and (F) 4 after $72 \mathrm{~h}$ incubation at $37{ }^{\circ} \mathrm{C}$. Data represent the mean of triplicate experiments.

This clearly evidenced that $\mathbf{H}_{3} \mathbf{L} \mathbf{1}$ substantially affected proliferation more efficiently than $\mathrm{H}_{2} \mathrm{~L} 2$, and complexes $\mathbf{1}$ and $\mathbf{2}$ more efficiently than $\mathbf{3}$ and $\mathbf{4}$. In general and taking into account the standard deviations of the $\mathrm{IC}_{50}$, perchlorate or acetate copper complexes $\mathbf{1}$ and $\mathbf{2}$ presented identical cytotoxic potencies on MDA-MB-231 cells. For perchlorate or acetate complexes $\mathbf{3}$ and $\mathbf{4}$ (derived from $\mathbf{H}_{2} \mathrm{~L} 2$ ), the reported $\mathrm{IC}_{50}$ were both determined as $>10 \mu \mathrm{M}$. In contrast to what has been previously observed, ${ }^{[50-52]} \mathrm{IC}_{50}$ values of the ligands were lower than those of their respective complexes, and ligand $H_{3} L 1$ is notably the most potent compound within the set. Metal-free hydrazone derivatives have previously showed good $\mathrm{IC}_{50}$ values on MDA-MB-231 cells. ${ }^{[53]}$ Nevertheless, this work highlights that the potent cytotoxic effect of ligand $H_{3} L 1$ is due only not to its PIH hydrazone moiety, but to its combination with the phenol and pyridine entities present as pendant arms in the hard-side of this ligand.

Table 2. $I C_{50}$ values of the ligands $H_{3} L 1$ and $H_{2} L 2$ and their copper(II) complexes 1-4 on MDA-MB-231 cells. The precursor involved in the synthesis of each compound is also indicated.

\begin{tabular}{ccc}
\hline Compound & $\mathrm{IC}_{50}[\mu \mathrm{M}]^{[a]}$ & Anion from copper salt \\
\hline $\mathbf{H}_{3} \mathbf{L} 1$ & $0.29 \pm 0.03$ & - \\
$\mathbf{H}_{2} \mathbf{L} 2$ & $4.30 \pm 0.50$ & - \\
$\mathbf{1}$ & $0.45 \pm 0.03$ & $\mathrm{ClO}_{4}^{-}$ \\
$\mathbf{2}$ & $0.49 \pm 0.01$ & $\mathrm{CH}_{3} \mathrm{COO}$ \\
$\mathbf{3}$ & $>10$ & $\mathrm{ClO}_{4}^{-}$ \\
$\mathbf{4}$ & $>10$ & $\mathrm{CH}_{3} \mathrm{COO}$ \\
\hline
\end{tabular}

[a] Determined after $72 \mathrm{~h}$ incubation in triplicate (mean \pm S.D).

Finally, the correlation between DNA interaction and cytotoxicity results shows that the compounds with higher DNA constant values provide lower cytotoxic effect on cancer cells. Consequently, it could be argued the interaction with DNA is probably not the main compound mechanism that induces cell death.

\section{Zinc and iron coordination and transchelation studies}

Geersing et. al reported that, in physiological conditions, $\mathrm{N}_{5}$ donor ligands can chelate intracellular metal ions, such as $\mathrm{Fe}(\mathrm{II})$, $\mathrm{Fe}(\mathrm{III})$ and $\mathrm{Zn}$ (II), and additionally, that copper complexes can exchange their copper(II) ions with these relevant metal ions. ${ }^{[54]}$ Intracellular chelation as a strategy to induce cancer cell death was particularly studied during the last years. ${ }^{[55]}$ Consequently, the discovery of new compounds with such a transchelation ability becomes an alternative strategy to develop potent anticancer drugs. 
Taking into consideration, firstly, the ability of similar reported Schiff base ligands to coordinate iron(II), iron(III) and zinc(II) ions, and secondly, the higher cytotoxic activity of ligand $\mathbf{H}_{3} \mathbf{L} \mathbf{1}$, and finally, the reduced cytotoxicity of complexes in comparison to ligands, we evaluated the ability of ligands $\mathrm{H}_{3} \mathbf{L 1}$ and $\mathrm{H}_{2} \mathrm{~L} 2$ to chelate $\mathrm{Fe}(\mathrm{II}), \mathrm{Fe}(\mathrm{III})$ and $\mathrm{Zn}$ (II) ions by absorption spectroscopy. Some changes in the ligands' absorption spectrum were noticed upon addition of $\mathrm{Fe}(\mathrm{II}), \mathrm{Fe}(\mathrm{III}), \mathrm{Zn}(\mathrm{II})$ or $\mathrm{Cu}(\mathrm{II})$ ions (Figure 8). Addition of 2 eq. of $\mathrm{Zn}(\mathrm{II})$ did not change the absorption profile of $\mathrm{H}_{3} \mathrm{~L} 1$ suggesting that no complex was formed. A contrario, the mixture of $\mathbf{H}_{2} \mathrm{~L} 2$ and 2 eq. of $\mathrm{Zn}$ (II) gave rise to a shoulder at ca. $400 \mathrm{~nm}$ that may be assigned to the dizinc complex by analogy with the dicopper complex. The addition of Fe(II) (Lewis borderline acid) to the solutions of both ligands induces a slight red shift of the bands corresponding to the hydrazone moiety. The band at $360 \mathrm{~nm}$ in the spectra is redshifted, suggesting that complexation with iron occurs mainly at the HBPAMFF $\left(\mathbf{H}_{3} \mathbf{L} \mathbf{1}\right)$ or BPMAMFF $\left(\mathbf{H}_{2} \mathbf{L} 2\right)$ pendant arm, instead of the PIH hydrazone group. In addition, a broad absorbance around $400-600 \mathrm{~nm}$ is observed that could be attributed to the Fe(II)-complexes formation.

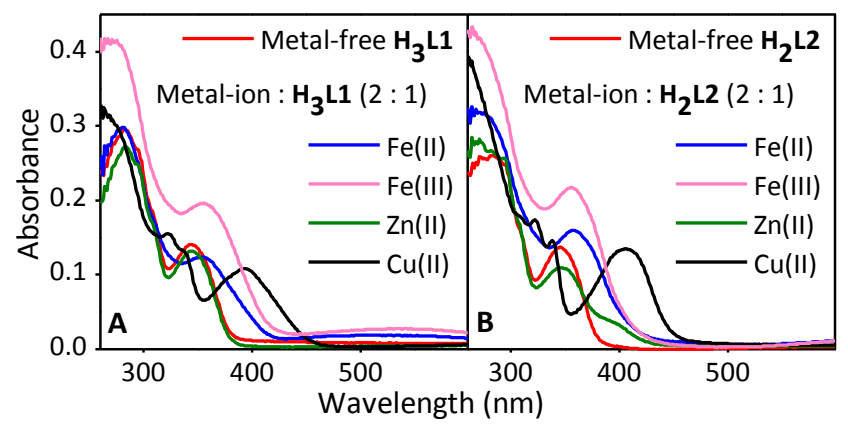

Figure 8. Absorption spectra of ligands $(A) \mathbf{H}_{3} \mathbf{L}$ and $(B) \mathbf{H}_{2} \mathrm{~L} 2,(10 \mu \mathrm{M})$ alone or in the presence of $\mathrm{Fe}(\mathrm{II}), \mathrm{Fe}(\mathrm{III}), \mathrm{Zn}$ (II) or $\mathrm{Cu}(\mathrm{II})$ in $2: 1$ metal ion : compounds mole ratio, in DMSO incubated at $37^{\circ} \mathrm{C}$ for $1 \mathrm{~h}$ under nitrogen atmosphere.

Finally, addition of $\mathrm{Fe}$ (III) produces large changes in the spectrum of the ligands. As observed for Fe(II) addition, a band at $360 \mathrm{~nm}$ in the spectra appeared. Upon complexation, an additional absorption comparable in magnitude to the absorption of the PIH and HBPAMFF $\left(\mathbf{H}_{3} \mathrm{~L} \mathbf{1}\right)$ or BPMAMFF $\left(\mathbf{H}_{2} \mathrm{~L} 2\right)$ fragments was observed in the spectra of the ligands at $400-$ $600 \mathrm{~nm}$. This absorption was assigned to complexation of ligands by $\mathrm{Fe}(\mathrm{III})$, taking into account that $\mathrm{Fe}^{\mathrm{III}}{ }_{2}$-complexes of similar ligands presented absorption bands in the $400-800 \mathrm{~nm}$ range. ${ }^{[56]}$ Altogether, these data suggest that both $\mathrm{H}_{3} \mathrm{~L} 1$ and $\mathrm{H}_{2} \mathrm{~L} 2$ could chelate $\mathrm{Fe}(\mathrm{II})$ and $\mathrm{Fe}(\mathrm{III})$, but only $\mathrm{H}_{2} \mathrm{~L} 2$ seems capable to coordinate $\mathrm{Zn}$ (II) to some extent as well.

A second series of experiments was done to assess whether the copper ions in complexes $\mathbf{2}$ and $\mathbf{4}$ could be displaced by iron or zinc (Figure 9).

Both complexes were incubated with 2 eq. of competing metal for $24 \mathrm{~h}$ at $37^{\circ} \mathrm{C}$. Figure 7 shows that addition of $\mathrm{Zn}(\mathrm{II})$ to solutions of $\mathbf{2}$ and $\mathbf{4}$ did not affect the absorption spectra of complexes suggesting that no transchelation occurred between $\mathrm{Cu}(\mathrm{II})$ and $\mathrm{Zn}(\mathrm{II})$. Conversely, incubation of $\mathbf{2}$ and $\mathbf{4}$ with Fe(II) induced an increase of absorbance at $360 \mathrm{~nm}$. It has to be noted


that $\mathrm{Fe}$ (II) salt absorbs light around $360 \mathrm{~nm}$. To rule out the contribution of iron, the sum of complexes and iron salts spectra was calculated. The increase observed is largely higher than the addition of the two spectra assuming the formation of di-Fe(II) complexes. Finally, the addition of $\mathrm{Fe}$ (III) salt produced an increase of absorbance at $360 \mathrm{~nm}$ only for $\mathbf{H}_{3} \mathbf{L} \mathbf{1}$. This interesting result seems to indicate that $\mathrm{Cu}(\mathrm{II})$ complexes derived from $\mathrm{N}_{2} \mathrm{O}$ donor set (Lewis hard base) transchelate with both ferric or ferrous iron, but $\mathrm{Cu}$ (II) complexes bearing $\mathrm{N}_{3}$-donor set (Lewis borderline base) are limited to Fe(II). However, measurement of iron cellular content should be performed to confirm the transchelator-like behaviour of these complexes and the iron parameters such as transferrin receptor and ferritin expressions should be checked as well.

\section{Cytotoxicity versus iron coordination}

The relationship between the cytotoxic activity of the compounds and their ability to coordinate essential ions is a crucial point to evaluate. In general, some relationships can be observed

Figure 9. Absorption spectra of complex 2 in the presence of $\mathrm{Fe}(\mathrm{II})(\mathrm{A}), \mathrm{Fe}$ (III) (C), $\mathrm{Zn}(\mathrm{II})(\mathrm{E})$; and complex 4 in the presence of $\mathrm{Fe}(\mathrm{II})$ (B), $\mathrm{Fe}(\mathrm{III})$ (D), $\mathrm{Zn}$ (II) $(F)$ in $2: 1$ metal ion : compounds mole ratio, in DMSO incubated at $37^{\circ} \mathrm{C}$ for $24 \mathrm{~h}$ under nitrogen atmosphere.

between the ability of compounds (followed by absorption spectroscopy) to sequester $\mathrm{Fe}(\mathrm{II}), \mathrm{Fe}$ (III) and $\mathrm{Zn}$ (II) ions from the physiological medium and the measured $\mathrm{IC}_{50}$ values. 
For instance, in both experiments, no relevant differences were observed between perchlorate and acetate copper complexes. It means that complexes $\mathbf{1}$ and $\mathbf{2}$ show similar cytotoxicity on cancer cells and transmetalation ability. In the same line, complexes $\mathbf{3}$ and $\mathbf{4}$ also share similar properties. Comparing ligands and their copper complexes, a similar conclusion can be found. The remarkably higher anticancer activity of the ligands correlates with their high potential to coordinate biological metals such as iron, zinc and copper, in comparison with the corresponding complexes. Besides, the lower $\mathrm{IC}_{50}$ values for the ligands suggest that cytotoxicity is probably due to chelation of metal ions in the cellular medium. Finally, ligand $\mathbf{H}_{3} \mathrm{~L} 1$ and its respective copper complexes 1 and 2 exhibited higher cytotoxic activity and affinity to $\mathrm{Fe}$ (III) than ligand $\mathrm{H}_{2} \mathrm{~L} 2$ (from BPMAMFF moiety). To sum up, we suggest that the notable cytotoxic activity of the compounds could be due to the dysregulation of iron and / or copper homeostasis that could induce, for example, perturbation of cell cycle and reactive oxygen species (ROS) generation. ${ }^{[55]}$

\section{Conclusions}

Two novel isoxazole-aroylhydrazone Schiff base ligands and their dicopper(II) complexes from perchlorate and acetate salts were synthesized and fully characterized by spectroscopic and analytical techniques. The absorption bands in the spectra of ligands and complexes were successfully assigned to the isoxazole-aroylhydrazone, and to the HBPAMFF or BPMAMFF moieties. Ligands and complexes stability was monitored by UVvis absorption. In DMSO, the six compounds showed high stability, while copper complexes were more stable than ligands under physiological conditions, probably due to the higher solubility of the complexes in aqueous medium. Both complexes and ligands interacted with DNA through non-intercalative modes. Metal-free ligands displayed fluorescent properties, while complexes were not fluorescent. The competitive EB displacement assay revealed a strong affinity of $\mathrm{Cu}_{2}$-complexes for DNA in the micromolar range. Compounds' cytotoxicity was examined on triple negative breast cancer cells by the MTT assay. The results evidenced that the HBPAMFF-derived ligand $\mathrm{H}_{3} \mathrm{~L} 1$ and its $\mathrm{Cu}_{2}$-complexes containing a phenol pendant arm in their structure showed much higher cytotoxicity than those derived from the BPMAMFF precursor. Surprisingly, ligands were more active against cancer cells than complexes. Nevertheless, copper complexes presented a better solubility and were structurally more stable in aqueous medium than ligands. In addition, the new ligands exhibited the in vitro ability to coordinate to $\mathrm{Fe}(\mathrm{II}), \mathrm{Fe}(\mathrm{III})$, and $\mathrm{Cu}(\mathrm{II})$, while copper(II) complexes derived from HBPAMFF seem able to exchange their $\mathrm{Cu}$ (II) ions with other biological metals, such as iron. Copper complexes developed as anti-cancer agents have been shown to induce cell death through several mechanisms such as proteasome inhibition, DNA damage or generation of ROS.[ Dalton Trans., 2017, 46,10758] The latter appears as the major anticancer mechanism of $\mathrm{Cu}$ (II) complexes by reduction of $\mathrm{Cu}(\mathrm{II})$ to $\mathrm{Cu}(\mathrm{II})$.[JBIC, 2012, 17, 409; JBIC, 2006, 11, 499; Dalton, 2009, 4488] Taken into account the transchelation capacity of the complexes 2 and $\mathbf{4}$, an iron depletion from the labile iron pool combined with potential generation of ROS could take place and induce more complex mechanisms of cell death. All these pathways should be explored, particularly the effect on iron metabolism (iron content, transferrin and ferritin expression) and on DNA synthesis which is dependent on the irondependent ribonucleotide reductase enzyme.

On the other hand, it is established that some copper(II) complexes are able to bind to DNA and can induce DNA double strand hydrolysis often driven by their phosphatase activity. We could demonstrate the in vitro ability of our complexes to interact with DNA but again, several questions arise. The lipophilicity of the complexes probably allows cellular internalization but are they capable of reaching the nucleus? Are they endowed with phosphatase activity? All these mechanisms of cell death will have to be explored in order to clear up the precise mode of action of these complexes. These experiments are ongoing and will be reported in due course.

\section{Experimental Section}

\section{Instrumentation}

${ }^{1} \mathrm{H}(400 \mathrm{MHz})$ and ${ }^{13} \mathrm{C}(100 \mathrm{MHz}) \mathrm{RMN}$ spectra were acquired on a Bruker Avance III HD-400 spectrometer. Chemical shifts are reported in ppm and calibrated to $2.50\left({ }^{1} \mathrm{H}\right)$ and $39.52\left({ }^{13} \mathrm{C}\right) \mathrm{ppm}$ relative to DMSO- $d_{6}$. Identification of the multiplicities of peaks are given as: $s$, singlet; $d$, doublet, $\mathrm{t}$, triplet; $\mathrm{m}$, multiplet; dd, doublet of doublet; br, broad. Coupling constants $J$ are expressed in Hertz. Two-dimensional nuclear magnetic resonance spectroscopy $\left({ }^{1} \mathrm{H}-{ }^{1} \mathrm{H} \mathrm{COSY}\right)$, heteronuclear single quantum coherence spectroscopy $\left({ }^{13} \mathrm{C}-{ }^{1} \mathrm{H}\right.$ HSQC), and heteronuclear multiple bond correlation $\left({ }^{13} \mathrm{C}-{ }^{1} \mathrm{H}\right.$ HMBC) spectra were used to confirm the NMR assignments. UV/Visible $(900-250 \mathrm{~nm})$ spectra were recorded on a Cary 100 (Agilent) or Cary 50 (Varian) spectrophotometers with a temperature controlled equipment. Mid-infrared (MIR) spectra (4000 $450 \mathrm{~cm}^{-1}$ ) were recorded on a Spectrum $400 \mathrm{FTIR} / \mathrm{FTFIR}$ spectrometer (Perkin-Elmer) with a resolution of $4 \mathrm{~cm}^{-1}$. Measurements (16 scans/sample) were carried out at room temperature in $\mathrm{KBr}$ pellets.

For X-Ray crystal structure determinations, a single crystal of each compound was selected, mounted onto a MiTeGen cryoloop and transferred into a cold nitrogen gas stream. Intensity data were collected with a Bruker Kappa APEX-II CCD diffractometer using a graphitemonochromated Mo $K \alpha$ radiation $(\lambda=0.71073 \AA)$ for ligand $\mathbf{H}_{2} \mathrm{L2}$ and complex 4, or with a Bruker Kappa APEX-II CCD diffractometer using a micro-focused $\mathrm{Cu} K \alpha$ radiation $(\lambda=1.54178 \AA)$ for ligand $H_{3} \mathrm{~L} 1$ and complex 1. Data collection of ligands and complexes was performed at $200 \mathrm{~K}$, with the Bruker APEXIII suite. Unit-cell parameters determinations, integrations and data reductions were carried out with SAINT program. SADABS was used for scaling and absorption corrections. The structures were solved with SHELXT ${ }^{[57]}$ and refined by full-matrix least-squares methods with SHELXL ${ }^{[58]}$ using Olex2 software package ${ }^{[59]}$ (for $\mathrm{H}_{3} \mathrm{~L} 1$ and 4) or WinGX suite ${ }^{[60]}$ (for $\mathbf{H}_{2} \mathrm{L2}$ and 1). All non-hydrogen atoms were refined anisotropically. Distance and angles were calculated with DIAMOND, MERCURY or PLATON softwares. These structures were deposited at the Cambridge Crystallographic Data Centre with numbers CCDC $1912561\left(\mathbf{H}_{2} \mathbf{L} 2\right), 1912562\left(\mathbf{H}_{3} \mathbf{L} \mathbf{1}\right), 1899672$ (complex 1), and 1899668 (complex 4) and can be obtained free of charge via www.ccdc.cam.ac.uk. 
Elemental analysis was performed on a ThermoElectron analyser equipment (Flash EA 1112). All the measurements were carried out in triplicate with $1 \%$ as the maximum standard deviation. Copper content in the complexes was estimated using inductively coupled plasma optical emission spectrometer (ICP-OES, Perkin-Elmer Optima 7300 DV). Samples were treated with nitric acid and diluted in water. Measurements were performed with the dye laser pulsed in the $324.7 \mathrm{~nm}$ line for copper. Conductivity measurements were performed at room temperature in an electrical conductivity $650 \mathrm{MA}$ Analyser using $1 \times 10^{-3} \mathrm{~mol} \mathrm{~L}^{-1}$ solutions of complexes in MeCN. Thermogravimetric curves were acquired in a Thermogravimetric Analyzer (Perkin Elmer, Pyris 1 TGA). TGA scans were performed from 25 to $900{ }^{\circ} \mathrm{C}$ at $10^{\circ} \mathrm{C} \mathrm{min}$ min $^{-1}$ under flowing dry air atmosphere. Curve optimization and calculations were processed in the Pyris v 8.0.0.0172 software. All data were processed by using software provided by the manufacturer.

\section{Chemicals}

All reagents and solvents were purchased from Acros Organics and Sigma-Aldrich, and used without further purification. The starting material 3-[(2-hydroxybenzyl)(2-pyridylmethyl)amine]-2-hydroxy-5-

methylbenzaldehyde (HBPAMFF) was synthesized from (2-chloromethyl4-methyl-6-formyl)phenol ${ }^{[61]} \quad$ (CMFF) and (2-hydroxybenzyl)(2pyridylmethyl)amine ${ }^{[56]}{ }^{[62]}$ as described previously. ${ }^{[63]} 2[$-bis(pyridylmethyl)aminomethyl]-4-methyl-6-formyl-phenol (BPMAMFF) was obtained from CMFF and bis-(2-pyridylmethyl)amine according to the described procedures. ${ }^{[61]}$ [63] Their spectroscopic features were in agreement with the literature. Ultrapure water (resistivity $<18 \mathrm{M} \Omega \mathrm{cm}$ ) obtained from a water purifier Milli-Q Gradient System A10 (Millipore, USA). Nitrogen gas (99.999\%) was from Linde-gases (Brazil). MWCNTs (110-170 nm diameter and 5-9 $\mu \mathrm{m}$ length) were from Sigma-Aldrich (USA). Sodium hydroxide $(98.0 \%, \mathrm{~m} / \mathrm{m})$, acetic acid $(65.0 \% \mathrm{~m} / \mathrm{v})$, boric acid $(99.8 \% \mathrm{~m} / \mathrm{m})$, phosphoric acid $(85.0 \%, \mathrm{~m} / \mathrm{v})$, potassium chloride and sodium acetate were obtained from Merck (Germany).

\section{Ligands' Syntheses}

HBPAMF-5-phenylisoxazole-3-carbohydrazone $\left(\mathrm{H}_{3} \mathbf{L} 1\right)$ : Compound $\mathrm{H}_{3} \mathrm{~L} 1$ was synthesized from HBPAMFF (2 mmol) and 5-phenylisoxazole3-carbohydrazide (PIH) (2 mmol), separately dissolved in $\mathrm{MeOH} / \mathrm{DCM}$ $1: 1(\mathrm{v} / \mathrm{v})(10 \mathrm{~mL})$. PIH was slowly added to the HBPAMFF solution. To evaporate DCM in the solution, the reaction flask was heated in an open atmosphere for some minutes. Then, the mixture was refluxed over $3 \mathrm{~h}$, and, after cooling to room temperature, the solid was separated by filtration and washed with cold acetonitrile. The white solid was dried under reduced pressure and recrystallized from acetonitrile to afford colourless crystals. M.p. $=174{ }^{\circ} \mathrm{C}$, yield $=1.05 \mathrm{~g}(1.9 \mathrm{mmol}, 96 \%)$. Elemental analysis calcd. (\%) $\mathrm{C}_{32} \mathrm{H}_{29} \mathrm{~N}_{5} \mathrm{O}_{4}\left(547.66 \mathrm{~g} \mathrm{~mol}^{-1}\right): \mathrm{C} 70.2, \mathrm{H} 5.3$ $\mathrm{N}$ 12.8; found: $\mathrm{C} 69.9, \mathrm{H} 5.4, \mathrm{~N} 13.2 .{ }^{1} \mathrm{H}$ NMR (400 MHz, DMSO- $\left.d_{6}\right): \delta$ 2.23 (s, $\left.3 \mathrm{H}, \mathrm{CH}_{3}\right), 3.69$ (s, $\left.2 \mathrm{H}, \mathrm{CH}_{2}\right), 3.72\left(\mathrm{~s}, 2 \mathrm{H}, \mathrm{CH}_{2}\right), 3.79\left(\mathrm{~s}, 2 \mathrm{H}, \mathrm{CH}_{2}\right)$, $6.75\left(\mathrm{~d}, 1 \mathrm{H},{ }^{3} \mathrm{~J}_{\mathrm{HH}}=7.6, \mathrm{H}_{\text {phenol-2}}\right), 6.78\left(\mathrm{~s}, 1 \mathrm{H}, \mathrm{H}_{\text {phenol-2 }}\right), 7.09\left(\mathrm{td}, 1 \mathrm{H},{ }^{3} \mathrm{~J}_{\mathrm{HH}}\right.$ $\left.=7.8,{ }^{4} J_{\mathrm{HH}}=1.6, \mathrm{H}_{\text {phenol-2 }}\right), 7.16\left(\mathrm{~s}, 1 \mathrm{H}, \mathrm{H}_{\text {phenol-1 }}\right), 7.21\left(\mathrm{dd}, 1 \mathrm{H},{ }^{3} J_{\mathrm{HH}}=7.6\right.$, $\left.{ }^{4} J_{H H}=1.1, \mathrm{H}_{\text {phenol-2 }}\right), 7.31\left(\mathrm{t}, 1 \mathrm{H},{ }^{3} J_{\mathrm{HH}}=2.6, \mathrm{H}_{\text {pyridine }}\right), 7.34\left(\mathrm{~s}, 1 \mathrm{H}, \mathrm{H}_{\text {phenol-1 }}\right)$ $7.42\left(\mathrm{~d}, 1 \mathrm{H},{ }^{3} \mathrm{~J}_{\mathrm{HH}}=7.8, \mathrm{H}_{\text {pyridine }}\right), 7.52\left(\mathrm{~s}, 1 \mathrm{H}, \mathrm{H}_{\text {isoxazol }}\right), 7.57(\mathrm{~m}, 2 \mathrm{H}$, $\left.2 \mathrm{H}_{\text {phenyl }}\right), 7.59$ (s, $\left.1 \mathrm{H}, \mathrm{H}_{\text {phenyl }}\right), 7.80$ (td, $\left.1 \mathrm{H},{ }^{3} \mathrm{~J}_{\mathrm{HH}}=7.7,{ }^{4} \mathrm{~J}_{\mathrm{HH}}=1.7, \mathrm{H}_{\text {pyridine }}\right)$, $7.99-7.96\left(\mathrm{~m}, 2 \mathrm{H}, 2 \mathrm{H}_{\text {phenyl }}\right), 8.56\left(\mathrm{~d}, 1 \mathrm{H},{ }^{3} \mathrm{~J}_{\mathrm{HH}}=4.2, \mathrm{H}_{\text {pyridine }}\right), 8.73(\mathrm{~s}, 1 \mathrm{H}$ $\mathrm{NCH}), 12.50(\mathrm{~s}, 1 \mathrm{H}, \mathrm{OH}), 10.87(\mathrm{~s}, \mathrm{br}, 2 \mathrm{H}, \mathrm{OH}$ and $\mathrm{NH}) \mathrm{ppm} .{ }^{13} \mathrm{C} \mathrm{NMR}$

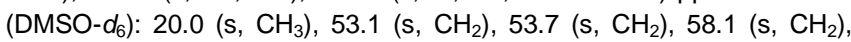
100.3 (s, $\left.\mathrm{C}_{\text {isoxazol }}\right), 115.5$ (s, $\left.\mathrm{C}_{\text {phenol-2) }}\right), 118.4$ (s, $\left.\mathrm{C}_{\text {phenol-1 }}\right), 118.8$ (s, $\mathrm{C}_{\text {phenol- }}$ 2), $122.5\left(\mathrm{~s}, \mathrm{C}_{\text {phenol-1 }}\right), 123.2\left(\mathrm{~s}, \mathrm{C}_{\text {phenol-2}}\right), 123.2\left(\mathrm{~s}, \mathrm{C}_{\text {pyridine }}\right), 124.4(\mathrm{~s}$, $\mathrm{C}_{\text {phenol-1) }}$ ), 125.9 (s, 2 $\left.\mathrm{C}_{\text {phenyl }}\right), 126.2$ (s, $\left.\mathrm{C}_{\text {phenyl }}\right), 127.6$ (s, $\left.\mathrm{C}_{\text {phenol-1) }}\right), 128.0$ (s $\mathrm{C}_{\text {pyridine }}$ ), 128.4 (s, $\left.\mathrm{C}_{\text {phenol-2) }}\right), 129.4$ (s, $\left.\mathrm{C}_{\text {phenyl }}\right), 130.0$ (s, $\mathrm{C}_{\text {phenol-2) }}$ ), 131.0 (s, 2 $\mathrm{C}_{\text {phenyl }}$ ), 132.2 (s, $\mathrm{C}_{\text {phenol-1) }}$ ), 137.0 (s, $\mathrm{C}_{\text {pyridine }}$ ), 148.7 (s, $\left.\mathrm{C}_{\text {pyridine }}\right), 149.5$ (s $\mathrm{N}=\mathrm{C}$ ), 154.5 (s, $\left.\mathrm{C}_{\text {phenol-1) }}\right), 154.9$ (s, $\left.\mathrm{C}_{\text {isoxazol }}\right), 156.5$ (s, $\left.\mathrm{C}_{\text {phenol-2) }}\right), 157.6$ (s, $\left.\mathrm{C}_{\text {pyridine }}\right), 158.7(\mathrm{~s}, \mathrm{C}=\mathrm{O}), 170.6\left(\mathrm{~s}, \mathrm{C}_{\text {isoxazol }}\right) \mathrm{ppm}$. FTIR $\left(\mathrm{KBr}, \mathrm{cm}^{-1}\right): 3440$ w, br (u OH), 3144 w, br (u NH), 1673 s (u C=O), 1615 m (u C=N), 1593 $\mathrm{s}(\delta \mathrm{NH}), 1443 \mathrm{~s},(\mathrm{u} \mathrm{N}-\mathrm{C}), 1350 \mathrm{~m}(\delta \mathrm{OH}), 1268 \mathrm{~s}(\mathrm{u} \mathrm{OCN}), 1237 \mathrm{~s}$ (u $\mathrm{C}-\mathrm{O}$ ), $1168 \mathrm{~m}$ (u N-N). Phenol-1: phenol central ring and phenol-2: phenol ring pendant arm.
BPMAMFF-5-phenylisoxazole-3-carbohydrazone $\left.\quad \mathbf{H}_{2} \mathbf{L} 2\right)$ : $\mathbf{P I H} \quad(1.5$ $\mathrm{mmol})$ dissolved in $\mathrm{MeOH} / \mathrm{DCM} 1: 1(\mathrm{v} / \mathrm{v})(10 \mathrm{~mL})$ was added dropwise to a solution of BPMAMFF $(1.5 \mathrm{mmol})$ in $\mathrm{MeOH}(10 \mathrm{~mL})$. The mixture reaction followed the same process followed to synthesize $\mathbf{H}_{3} \mathrm{~L} 1$. Single crystals were obtained by dissolving the white solid in acetonitrile. M.p. = $159-162{ }^{\circ} \mathrm{C}$, yield $=0.67 \mathrm{~g}(1.3 \mathrm{mmol}, 87 \%)$. Elemental analysis calcd. (\%) for $\mathrm{C}_{31} \mathrm{H}_{28} \mathrm{~N}_{6} \mathrm{O}_{3}\left(532.65 \mathrm{~g} \mathrm{~mol}^{-1}\right.$ ): $\mathrm{C}$ 69.9, $\mathrm{H}$ 5.3, N 15.8; found: C 70.5, $\mathrm{H} 5.4, \mathrm{~N}$ 16.5. ${ }^{1} \mathrm{H}$ NMR $\left(400 \mathrm{MHz}\right.$, DMSO- $\left.d_{6}\right): \delta 2.24\left(\mathrm{~s}, 3 \mathrm{H}, \mathrm{CH}_{3}\right), 3.74$ (s, $2 \mathrm{H}, \mathrm{CH}_{2}$ ), 3.81 (s, $\left.4 \mathrm{H}, 2 \mathrm{CH}_{2}\right), 7.17$ (s, $\left.1 \mathrm{H}, \mathrm{H}_{\text {phenol }}\right), 7.27$ (td, $2 \mathrm{H},{ }^{3} J_{\mathrm{HH}}=6.6$, $\left.{ }^{4} J_{\mathrm{HH}}=0.8,2 \mathrm{H}_{\text {pyridine }}\right), 7.39\left(\mathrm{~s}, 1 \mathrm{H}, \mathrm{H}_{\text {phenol }}\right), 7.45\left(\mathrm{~d}, 2 \mathrm{H},{ }^{3} J_{\mathrm{HH}}=7.8\right.$, $\left.2 \mathrm{H}_{\text {pyridine }}\right), 7.52\left(\mathrm{~s}, 1 \mathrm{H}, \mathrm{H}_{\text {isoxazol }}\right), 7.56-7.57\left(\mathrm{~m}, 2 \mathrm{H}, 2 \mathrm{H}_{\text {phenyl }}\right), 7.58(\mathrm{~s}, 1 \mathrm{H}$, $\mathrm{H}_{\text {phenyl) }}$, 7.77 (td, $\left.2 \mathrm{H},{ }^{3} \mathrm{~J}_{\mathrm{HH}}=7.7,{ }^{4} \mathrm{~J}_{\mathrm{HH}}=1.7,2 \mathrm{H}_{\text {pyridine }}\right), 7.98-7.96(\mathrm{~m}, 2 \mathrm{H}$ $\left.2 \mathrm{H}_{\text {phenyl }}\right), 8.83(\mathrm{~s}, 1 \mathrm{H}, \mathrm{NCH}), 8.52\left(\mathrm{~d}, 2 \mathrm{H},{ }^{3} \mathrm{~J}_{\mathrm{HH}}=4.1,2 \mathrm{H}_{\text {pyridine }}\right) 11.66$ (s, $1 \mathrm{H}, \mathrm{NH}), 12.42(\mathrm{~s}, 1 \mathrm{H}, \mathrm{OH}) \mathrm{ppm} .{ }^{13} \mathrm{C}$ NMR (DMSO-d $\left.d_{6}\right): 20.0\left(\mathrm{~s}, \mathrm{CH}_{3}\right)$, $53.8\left(\mathrm{~s}, \mathrm{CH}_{2}\right), 58.6\left(\mathrm{~s}, 2 \mathrm{CH}_{2}\right), 100.3$ (s, $\left.\mathrm{C}_{\text {isoxazol }}\right), 119.0$ (s, $\left.\mathrm{C}_{\text {phenol }}\right), 122.3$

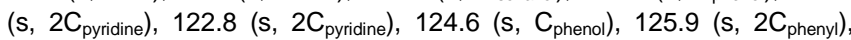
126.2 (s, $\mathrm{C}_{\text {phenyl }}$ ), 126.9 (s, $\mathrm{C}_{\text {phenol }}$ ), 127.4 (s, $\mathrm{C}_{\text {phenol }}$ ), 129.4 (s, 2 $\mathrm{C}_{\text {phenyl }}$ ),


148.7 (s, 2C $\left.\mathrm{C}_{\text {pyridine }}\right), 154.6$ (s, $\left.\mathrm{C}_{\text {phenol }}\right), 154.9$ (s, $\left.\mathrm{C}_{\text {isoxazol }}\right), 158.3$ (s, 2 $\left.\mathrm{C}_{\text {pyridine }}\right), 158.8(\mathrm{~s}, \mathrm{C}=\mathrm{O}), 170.6\left(\mathrm{~s}, \mathrm{C}_{\text {isoxazol }}\right)$ ppm. FTIR $\left(\mathrm{KBr}, \mathrm{cm}^{-1}\right): 3433$ w, br (u OH), 3136 w, br (u NH), 1676 s (u C=O), 1617 m (u C=N), 1592 $\mathrm{s}(\delta \mathrm{NH}), 1445 \mathrm{~s},(\mathrm{u} N-\mathrm{C}), 1352 \mathrm{~m}(\delta \mathrm{OH}), 1266 \mathrm{~s}(\mathrm{u} \mathrm{OCN}), 1239 \mathrm{~s}$ (u C-O), $1166 \mathrm{~m}$ (u N-N).

\section{Copper Complexes' Syntheses}

1 and 3 were prepared from copper(II) perchlorate hexahydrate and $\mathbf{H}_{3} \mathrm{~L} \mathbf{1}$ and $H_{2} L 2$, respectively, while complexes 2 and $\mathbf{4}$ were obtained from copper(II) acetate monohydrate and $\mathbf{H}_{3} \mathrm{~L} 1$ and $\mathbf{H}_{2} \mathrm{~L} 2$, correspondingly.

Caution! Perchlorate salts of metal complexes containing organic ligands are potentially explosive and should be handled with care. Only small amounts should be prepared.

Complex 1. $\mathbf{H}_{3} \mathrm{~L} 1$ (0.5 mmol) was dissolved in $\mathrm{MeOH} / \mathrm{DCM} 1: 1(10 \mathrm{~mL})$ Then, $\mathrm{Cu}\left(\mathrm{ClO}_{4}\right)_{2} \cdot 6 \mathrm{H}_{2} \mathrm{O}(1 \mathrm{mmol})$ in $\mathrm{MeOH}(3 \mathrm{~mL})$ was added dropwise to the yellow ligand solution. The dark green reaction mixture was heated and stirred for $40 \mathrm{~min}$. After that, $\mathrm{KOH}(1 \mathrm{M}, 1.5 \mathrm{mmol}, 1.5 \mathrm{~mL}$ in $\mathrm{MeOH})$ was added. Stirring was maintained further 20 minutes. After $12 \mathrm{~h}$ at room temperature, the product was filtered and washed with ice-cold $\mathrm{MeOH}$. Then, $\mathrm{MeOH}$ was removed under reduced pressure. Yield $=0.46$ $\mathrm{g}(0.49 \mathrm{mmol}, 99 \%)$. The dark green solid was recrystallized by slow evaporation in DMSO, forming single crystals. Elemental analysis (\%) calcd. for $\left[\mathrm{Cu}_{2}\left(\mathrm{C}_{32} \mathrm{H}_{26} \mathrm{~N}_{5} \mathrm{O}_{4}\right)\left(\mathrm{ClO}_{4}\right)(\mathrm{DMSO})\left(\mathrm{H}_{2} \mathrm{O}\right)\right] \cdot \mathrm{DMSO} \quad(945.38 \mathrm{~g}$ $\mathrm{mol}^{-1}$ ): C 45.7, H 4.3, N 7.4; found: C 44.7, H 4.0, N 7.0. ICP-OES calcd.: $\mathrm{Cu} 13.4$; found: 13.1. In the TGA analysis, the weight loss was approximately $2.0 \%$ between 100 and $137{ }^{\circ} \mathrm{C}$, corresponding to the removal of the coordinated water molecule (calcd 1.9\%). On the other hand, the weight loss related to the removal of the uncoordinated molecule of DMSO was observed at a higher temperature, finishing a around $250{ }^{\circ} \mathrm{C}$ (Fig. S7). Molar conductivity measurements in acetonitrile indicate that complex 1 behaves as a non-electrolyte. FTIR $\left(\mathrm{KBr}, \mathrm{cm}^{-1}\right)$ : $3428 \mathrm{~m}$, br (u OH), $1610 \mathrm{~m}(\mathrm{U} \mathrm{C}=\mathrm{N}), 1443 \mathrm{~m},(\mathrm{u} \mathrm{N}-\mathrm{C}), 1302 \mathrm{~m}$, sh (u OCN), $1285 \mathrm{~s}$ (u C-O), $1174 \mathrm{w}(\mathrm{u} \mathrm{N}-\mathrm{N}), 1097 \mathrm{~s}\left(\mathrm{U}_{3}\right.$ asym $\left.\mathrm{ClO}_{4}{ }^{-}\right), 1022 \mathrm{~m}$ $\left(\mathrm{U}_{4} \mathrm{ClO}_{4}^{-}\right), 622 \mathrm{~m}\left(\mathrm{u}_{3} \mathrm{sym}^{-} \mathrm{ClO}_{4}^{-}\right)$.

Complex 2. Complex 2 was prepared by heating for $40 \mathrm{~min}$ the mixture obtained by the dropwise addition of copper(II) acetate monohydrate ( 0.5 $\mathrm{mmol}$ in $10 \mathrm{~mL} \mathrm{MeOH}$ ) to $\mathbf{H}_{3} \mathrm{~L} \mathbf{1}(0.25 \mathrm{mmol})$ in $\mathrm{MeOH} / \mathrm{DCM} 1: 1(10 \mathrm{~mL})$ After one day, the dark green solid was filtered at room temperature and washed with ice-cold $\mathrm{MeOH}$. Then, the product was dried under reduced pressure. Yield $=0.20 \mathrm{~g}(0.25 \mathrm{mmol}, \sim 99 \%)$. Elemental analysis $(\%)-$ calcd. for $\left[\mathrm{Cu}_{2}\left(\mu-\mathrm{OOCCH}_{3}\right)\left(\mathrm{C}_{32} \mathrm{H}_{26} \mathrm{~N}_{5} \mathrm{O}_{4}\right)\left(\mathrm{H}_{2} \mathrm{O}\right)_{2}\right] \cdot 2 \mathrm{H}_{2} \mathrm{O}\left(802.78 \mathrm{~g} \mathrm{~mol}^{-1}\right)$ : C 50.9, H 4.7, N 8.7; found: C 50.5, H 4.4, N 8.6. ICP-OES calcd.: $\mathrm{Cu}$ 15.8; found: 16.0. The TGA analysis exhibited a weight loss of approximately $4.2 \%$ between 25 and $72{ }^{\circ} \mathrm{C}$, corresponding to the removal of two hydration water molecules (calcd $4.5 \%$ ). The weight loss related to the removal of the coordinated water molecules and the acetato ligand was also observed (Fig S7). Molar conductivity measured in acetonitrile 
indicates complex 2 performs as a non-electrolyte. FTIR $\left(\mathrm{KBr}, \mathrm{cm}^{-1}\right)$ : $3421 \mathrm{~m}$, br (u OH), $1611 \mathrm{~m}(\mathrm{u} \mathrm{C}=\mathrm{N}), 1593 \mathrm{w}(\delta \mathrm{NH}), 1450 \mathrm{~m}$, sh (u N-C), 1302 w, (u OCN), 1285 m (u C-O), 1175 w (u N-N).

Complex 3. The same procedure was followed as for complex 1 , but using copper(II) perchlorate hexahydrate $(0.8 \mathrm{mmol})$ and $\mathbf{H}_{2} \mathrm{~L} 2 \quad(0.4$ $\mathrm{mmol}$ ) in $\mathrm{MeOH}(10 \mathrm{~mL})$. After $40 \mathrm{~min}, \mathrm{KOH}(0.8 \mathrm{mmol})$ was added. Stirring was maintained further 20 minutes. After one day, the dark green solid was filtered at room temperature and washed with ice-cold $\mathrm{MeOH}$. The product was dried under reduced pressure. Yield $=0.40 \mathrm{~g}(0.38$ mmol, 95\%). Elemental analysis (\%) - calcd. for $\left[\mathrm{Cu}_{2}\left(\mathrm{C}_{31} \mathrm{H}_{27} \mathrm{~N}_{6} \mathrm{O}_{3}\right)\left(\mathrm{ClO}_{4}\right)\left(\mathrm{H}_{2} \mathrm{O}\right)_{2}\right]\left(\mathrm{ClO}_{4}\right)_{2} \cdot 3 \mathrm{H}_{2} \mathrm{O}\left(1047.19 \mathrm{~g} \mathrm{~mol}^{-1}\right): \mathrm{C} 35.6$, H 3.6, N 8.0; found: C 34.8, H 3.5, N 7.7. ICP-OES calcd.: Cu 12.1; found: 13.1. In the TGA analysis, the weight loss was approximately $5.0 \%$ (calcd $5.2 \%$ ) between 25 and $108{ }^{\circ} \mathrm{C}$, corresponding to the removal of the three hydration water molecules. The weight loss related to the removal of the coordinated water molecules and the three perchlorate ions was observed as well (Fig. S7). Molar conductivity in acetonitrile (334 $\mathrm{ohm}^{-1} \mathrm{~cm}^{2} \mathrm{~mol}^{-1}$ ) correlates pretty well with a $1: 2$ electrolyte system. FTIR (KBr, cm $\left.{ }^{-1}\right): 3444 \mathrm{~m}$, br (u OH), $1612 \mathrm{~m}(\mathrm{u} \mathrm{C}=\mathrm{N}), 1593 \mathrm{w}(\delta$ $\mathrm{NH}), 1445 \mathrm{~m}$, (u N-C), $1261 \mathrm{w}$, sh (u OCN), $1286 \mathrm{~s}$ (u C-O), $1108 \mathrm{~s}$ (U asym $\left.\mathrm{ClO}_{4}^{-}\right), 1031 \mathrm{~m}$, sh $\left(\mathrm{U}_{4} \mathrm{ClO}_{4}^{-}\right), 625 \mathrm{~m}\left(\mathrm{U}_{3}\right.$ sym $\left.\mathrm{ClO}_{4}^{-}\right)$.

Complex 4. $\mathbf{H}_{2} \mathrm{~L} 2(0.4 \mathrm{mmol})$ was dissolved in $10 \mathrm{~mL} \mathrm{MeOH}$ and copper(II) acetate monohydrate $(0.8 \mathrm{mmol}$ in $10 \mathrm{~mL} \mathrm{MeOH})$ was slowly added. The next steps were identical to those previously used to synthesize 1. Yield $=0.32 \mathrm{~g}(0.39 \mathrm{mmol}, 98 \%)$. The dark green solid was recrystallized by slow evaporation in DMF and single crystals were obtained. Elemental analysis (\%) - calcd. for $\left[\mathrm{Cu}_{2}\left(\mu-\mathrm{OOCCH}_{3}\right)\left(\mathrm{C}_{31} \mathrm{H}_{26} \mathrm{~N}_{6} \mathrm{O}_{3}\right)\left(\mathrm{OOCCH}_{3}\right)\left(\mathrm{H}_{2} \mathrm{O}\right)\right] \cdot 2 \mathrm{H}_{2} \mathrm{O}\left(829.79 \mathrm{~g} \mathrm{~mol}^{-1}\right)$ : C 50.7, H 4.6, N 10.1; found: C 50.7, H 4.6, N 10.4. ICP-OES calcd.: $\mathrm{Cu}$ 15.3; found: 15.3. The TGA analysis showed a weight loss of around $5.2 \%$ (calcd $5.4 \%$ ) between 25 and $142{ }^{\circ} \mathrm{C}$, corresponding to the removal of the two hydration water molecules and half of the amount of coordinated water. The weight loss corresponding to the removal of the coordinated acetate ions, altogether with the rest of the coordinated amount of water, was also detected (Fig. S7). Molar conductivity measured in acetonitrile indicates that complex 4 acts as a nonelectrolyte. FTIR (KBr, cm $\left.{ }^{-1}\right): 3428 \mathrm{~m}$, br (u OH), $1610 \mathrm{~m}(\mathrm{u} \mathrm{C}=\mathrm{N}), 1440$ m, sh (u N-C), 1306 m, (u OCN), 1284 m (u C-O), 1176 w (u N-N).

\section{In vitro DNA interaction with the ligands and complexes}

Titration studies by uv-visible spectroscopy: Solid ct-DNA was dissolved (2 $\mathrm{mg} \mathrm{mL}^{-1}, 50 \mathrm{mM}$ Tris- $\mathrm{HCl}$ and $50 \mathrm{mM} \mathrm{NaCl}, \mathrm{pH} 7.40$ ) and kept cold overnight. DNA concentration per nucleotide (dil. $20 \mathrm{x}$ ) was calculated at $260 \mathrm{~nm}\left(\varepsilon=6600 \mathrm{M}^{-1} \mathrm{~cm}^{-1}\right)$ and the absorbance ratio at $260 / 280 \mathrm{~nm}(1.8-1.9)$ indicated that the solution was sufficiently free of protein. Ct-DNA stock solution was stored at $-20{ }^{\circ} \mathrm{C}$ until use. Stock solutions of the compounds $(1 \mathrm{mM})$ were prepared in DMSO. Absorption spectra of the compounds $(25 \mu \mathrm{M})$ in $50 \mathrm{mM}$ Tris- $\mathrm{HCl}$ pH 7.4 / DMSO 9:1 were measured between $250-600 \mathrm{~nm}$ at $25{ }^{\circ} \mathrm{C}$. Aliquots of DNA solution $(0-50 \mu \mathrm{M}$ final concentration) were gradually added to the solutions and subtracted to the reference solution.

Titration studies by fluorescence spectroscopy: The emission spectra of ligand solutions $(5 \mu \mathrm{M})$ in $50 \mathrm{mM}$ Tris- $\mathrm{HCl}, 50 \mathrm{mM} \mathrm{NaCl}, \mathrm{pH}$ 7.40 / DMSO 99:1, with excitation wavelength at $350 \mathrm{~nm}$ were recorded in a Perkin Elmer spectrofluorimeter LS 55 with $6 \mathrm{~nm}$ of entrance and exit slits at $25^{\circ} \mathrm{C}$. Ligand solution was titrated by CT-DNA $(0-120 \mu \mathrm{M})$ by monitoring the emission intensity in the range $450-650 \mathrm{~nm}$. Free ctDNA solution did not show any fluorescence emission in the tested range. Blank fluorescence spectra were measured and subtracted from sample emission spectra.

Competitive fluorescence displacement assay: DNA-EB complex was prepared at saturated binding sites, that is, one molecule of $E B(5 \mu \mathrm{M})$ per two pairs of DNA bases $(10 \mu \mathrm{M})(4: 1$ DNA nucleotides : EB mole ratio). ${ }^{[64]}$ Titration of ct-DNA - EB mixture in $50 \mathrm{mM}$ Tris- $\mathrm{HCl}, 50 \mathrm{mM}$ $\mathrm{NaCl}, \mathrm{pH} 7.40$ by complexes was done by adding increasing amounts of complexes $(0-50 \mu \mathrm{M})$ and monitoring the emission spectrum between 575 and $775 \mathrm{~nm}$.

\section{In vitro Cytotoxic Activity}

Cell lines and culture conditions: MDA-MB-231 cells were cultivated in Dulbecco's Modified Eagle Medium (DMEM) supplemented with 10\% fetal bovine serum and $1 \%$ antibiotic mixture. Cells were grown in atmosphere containing $5 \% \mathrm{CO}_{2}$ at $37^{\circ} \mathrm{C}$.

Cell viability assay: Stock solutions of compounds at $1 \mathrm{mM}$ were prepared in DMSO and sterilized through $0.20 \mu \mathrm{m}$ PTFE-20/25 filter. To evaluate the biological activity of the ligands and complexes cell viability was estimated using the colorimetric 3-(4,5-dimethylthiazol-2-yl)-2,5diphenyltetrazolium bromide (MTT)-based assay. Cells were seeded at 2 $\times 10^{3}$ cells/well $(100 \mu \mathrm{L})$ in 96 -well plate. After $24 \mathrm{~h}$, cell medium was aspirated and cells were treated with various concentrations of the ligands and complexes $(0.01-10 \mu \mathrm{M})$. Compounds were diluted to desired concentration in cell medium containing $1 \%$ DMSO. In the untreated control wells, DMSO was added to $1 \%$ final concentration. Wells were incubated for another $72 \mathrm{~h}$ at $37{ }^{\circ} \mathrm{C}$ under $5 \% \mathrm{CO}_{2}$.

To determine the growth inhibitory effect, MTT $\left(0.5 \mathrm{mg} \mathrm{mL}^{-1}\right.$ in culture medium, $20 \mu \mathrm{L} /$ well) was added, and plates were incubated for $3 \mathrm{~h}$ at $37^{\circ} \mathrm{C}$. Supernatants were discarded and DMSO $(200 \mu \mathrm{L})$ was added to each well. Then, the plate content was gently mixed for some minutes in a variable-speed rocker. Absorbance at $\lambda=560 \mathrm{~nm}$ was measured with a microplate reader (Fluostar Optima, BMG Labtech). All the values were corrected from background absorbance. The ratio of the absorbance of treated to untreated cells gives the percentage of surviving cells. The percentage of cell viability (\%) relative to the untreated control cells versus the concentration $(\mu \mathrm{M})$ of compound was plotted and fitted to a sigmoidal logistic function. Finally, the concentration decreasing cell proliferation by $50 \%\left(\mathrm{IC}_{50}\right)$ was calculated by interpolating from the resulting equation of the curves. The reported $\mathrm{IC}_{50}$ values present as a means of triplicate experiments (mean \pm S.D).

\section{Iron and zinc competition studies}

Solutions of ligands $\mathbf{H}_{3} \mathbf{L} \mathbf{1}, \mathbf{H}_{2} \mathbf{L} 2$ and copper(II) complexes 1-4 (10 $\mu \mathrm{M}$ in DMSO) were supplemented with iron(II) chloride, iron(III) chloride or zinc(II) chloride $(20 \mu \mathrm{M})$ and mixtures were incubated at $37{ }^{\circ} \mathrm{C}$ in a shaker under nitrogen atmosphere. The absorption spectrum of the solutions was measured after an incubation of $24 \mathrm{~h}$.

\section{Circular dichroism}

Circular dichroism spectra were recorded on a J-815 CD spectrometer (JASCO) at $20^{\circ} \mathrm{C}$ in $1-\mathrm{cm}$ pathlength quartz cuvette between 235 and $340 \mathrm{~nm}$. Temperature control was provided by a Peltier thermostat. All spectra were accumulated 5 times with bandwidth of $1.0 \mathrm{~nm}$ and a resolution of $0.1 \mathrm{~nm}$ at a scan speed of $50 \mathrm{~nm} / \mathrm{min}$. The spectra were baseline-corrected and smoothed using the spectra manager software provided with the instrument. spectra were measured at $\mathrm{pH} 7.0$ and $\mathrm{T}=$ $20^{\circ} \mathrm{C}$ using a $50 \mu \mathrm{M}$ solution of ct-DNA in $5 \mathrm{mM}$ Tris- $\mathrm{HCl} / 50 \mathrm{mM} \mathrm{NaCl}$ buffer.

\section{Acknowledgements}

Nicolás A. Rey wishes to thank FAPERJ (Fundação Carlos Chagas Filho de Amparo à Pesquisa do Estado do Rio de Janeiro, Brazil) and CNPq (Conselho Nacional de Desenvolvimento Científico e Tecnológico, Brazil) for the 
research fellowships awarded. FINEP and FAPEMIG are also gratefully acknowledged for the financial support. J. P. Rada is grateful for the CAPES (Coordenação de Aperfeiçoamento de Pessoal de Nível Superior, Brazil) fellowship: PDSE88881.187965/2018-0, as well as for the doctoral scholarship supported by CAPES and CNPq. In addition, Prof. Ricardo Q. Aucélio (Department of Chemistry, PUC-Rio) is gratefully acknowledged for the elemental analyses.

\section{Conflict of Interest}

The authors declare no conflict of interest.

Keywords: copper(II) complexes • aroylhydrazonic ligands • antitumor agents $\cdot \mathrm{DNA} \cdot$ cytotoxicity

\section{References}

[1] R. A. Festa, D. J. Thiele, Curr. Biol. CB 2011, 21, R877-R883.

[2] M. Wehbe, A. W. Y. Leung, M. J. Abrams, C. Orvig, M. B. Bally, Dalton Trans. 2017, 46, 10758-10773.

[3] C. Duncan, A. R. White, Metallomics 2012, 4, 127-138.

[4] C. Santini, M. Pellei, V. Gandin, M. Porchia, F. Tisato, C. Marzano, Chem. Rev. 2014, 114, 815-862.

[5] L. Ruiz-Azuara, M. E. Bravo-Gomez, Curr. Med. Chem. 2010, 17, 3606-3615.

[6] D. Denoyer, S. A. S. Clatworthy, M. A. Cater, in Met.-Drugs Dev. Action Anticancer Agents (Eds.: A. Sigel, H. Sigel, E. Freisinger, R.K.O. Sigel), Walter De Gruyter Gmbh, Berlin, 2018, pp. 469-506.

[7] R. Galindo-Murillo, J. C. García-Ramos, L. Ruiz-Azuara, T. E. Cheatham III, F. CortésGuzmán, Nucleic Acids Res. 2015, 43, 53645376.

[8] E. W. Ainscough, A. M. Brodie, W. A. Denny, G. J. Finlay, S. A. Gothe, J. D. Ranford, J. Inorg. Biochem. 1999, 77, 125133.

[9] W. Y. Lee, P. P. F. Lee, Y. K. Yan, M. Lau, Metallomics 2010, 2, 694-705.

[10] M. Cindrić, A. Bjelopetrović, G. Pavlović, V. Damjanović, J. Lovrić, D. MatkovićČalogović, V. Vrdoljak, New J. Chem. 2017, 41, 2425-2435.

[11] D. Senthil Raja, N. S. P. Bhuvanesh, K. Natarajan, Inorganica Chim. Acta 2012, 385, 81-93.
[12] E. Ramachandran, V. Gandin, R. Bertani, P. Sgarbossa, K. Natarajan, N. S. P. Bhuvanesh, A. Venzo, A. Zoleo, A. Glisenti, A. Dolmella, et al., J. Inorg. Biochem. 2018, 182, 18-28.

[13] C. Fan, J. Zhao, B. Zhao, S. Zhang, J. Miao, Chem. Res. Toxicol. 2009, 22, 1517-1525.

[14] Q. Mo, J. Deng, Y. Liu, G. Huang, Z. Li, P. Yu, Y. Gou, F. Yang, Eur. J. Med. Chem. 2018, 156, 368-380.

[15] M. Jopp, J. Becker, S. Becker, A. Miska, V. Gandin, C. Marzano, S. Schindler, Eur. J. Med. Chem. 2017, 132, 274-281.

[16] S. S. Massoud, F. R. Louka, G. T. Ducharme, R. C. Fischer, F. A. Mautner, J. Vančo, R. Herchel, Z. Dvořák, Z. Trávníček, J. Inorg. Biochem. 2018, 180, 39-46.

[17] C. Fernandes, A. Neves, A. J. Bortoluzzi, A. S. Mangrich, E. Rentschler, B. Szpoganicz, E. Schwingel, Inorganica Chim. Acta 2001, $320,12-21$.

[18] A. Neves, L. M. Rossi, A. J. Bortoluzzi, B. Szpoganicz, C. Wiezbicki, E. Schwingel, W. Haase, S. Ostrovsky, Inorg. Chem. 2002, 41, 1788-1794.

[19] P. Karsten, A. Neves, A. J. Bortoluzzi, M. Lanznaster, V. Drago, Inorg. Chem. 2002, 41, 4624-4626.

[20] M. Lanznaster, A. Neves, A. J. Bortoluzzi, B. Szpoganicz, E. Schwingel, Inorg. Chem. 2002, 41, 5641-5643.

[21] A. Horn, I. Vencato, A. J. Bortoluzzi, R. Hörner, R. A. N. Silva, B. Spoganicz, V. Drago, H. Terenzi, M. C. B. de Oliveira, R. Werner, et al., Inorganica Chim. Acta 2005, 358, 339-351.

[22] E. Longhinotti, J. B. Domingos, B. Szpoganicz, A. Neves, F. Nome, Inorganica Chim. Acta 2005, 358, 2089-2092.

[23] A. Neves, M. Lanznaster, A. J. Bortoluzzi, R. A. Peralta, A. Casellato, E. E. Castellano, P. Herrald, M. J. Riley, G. Schenk, J. Am. Chem. Soc. 2007, 129, 7486-7487.

[24] N. A. Rey, A. Neves, A. J. Bortoluzzi, C. T. Pich, H. Terenzi, Inorg. Chem. 2007, 46, 348-350.

[25] N. A. Rey, A. Neves, P. P. Silva, F. C. S. Paula, J. N. Silveira, F. V. Botelho, L. Q. Vieira, C. T. Pich, H. Terenzi, E. C. Pereira- 
Maia, J. Inorg. Biochem. 2009, 103, 13231330.

[26] L. F. Esteves, N. A. Rey, H. F. Dos Santos, L. A. S. Costa, Inorg. Chem. 2016, 55, 28062818.

[27] D. Montagner, V. Gandin, C. Marzano, A. Erxleben, J. Inorg. Biochem. 2015, 145, 101-107.

[28] J. P. Rada, B. S. M. Bastos, L. Anselmino, C. H. J. Franco, M. Lanznaster, R. Diniz, C. O. Fernandez, M. Menacho-Marquez, A. M. Percebom, N. A. Rey, Inorg. Chem. 2019, 58, 8800-8819.

[29] D. R. Richardson, Antimicrob. Agents Chemother. 1997, 41, 2061.

[30] J. Zhu, J. Mo, H. Lin, Y. Chen, H. Sun, Bioorg. Med. Chem. 2018, 26, 3065-3075.

[31] R. Jovito, A. Neves, A. J. Bortoluzzi, M. Lanznaster, V. Drago, W. Haase, Inorg. Chem. Commun. 2005, 8, 323-327.

[32] S. Uozumi, H. Furutachi, M. Ohba, H. Ōkawa, D. E. Fenton, K. Shindo, S. Murata, D. J. Kitko, Inorg. Chem. 1998, 37, 62816287.

[33] S. M. G. Leite, L. M. P. Lima, S. Gama, F. Mendes, M. Orio, I. Bento, A. Paulo, R. Delgado, O. Iranzo, Inorg. Chem. 2016, 55, 11801-11814.

[34] G. B. Deacon, R. J. Phillips, Coord. Chem. Rev. 1980, 33, 227-250.

[35] U. Kumar, J. Thomas, N. Thirupathi, Inorg. Chem. 2010, 49, 62-72.

[36] J. Kalia, R. T. Raines, Angew. Chem. Int. Ed. Engl. 2008, 47, 7523-7526.

[37] B. J. M. L. Ferreira, P. Brandão, M. Meireles, F. Martel, A. Correia-Branco, D. M.

Fernandes, T. M. Santos, V. Félix, J. Inorg. Biochem. 2016, 161, 9-17.

[38] A. Mandal, P. Bhattacharya, A. K. Das, A. Basak, Tetrahedron 2019, 75, 1975-1987.

[39] R. Fekri, M. Salehi, A. Asadi, M. Kubicki, Polyhedron 2017, 128, 175-187.

[40] J. P. Rada, B. S. M. Bastos, L. Anselmino, C. H. J. Franco, M. Lanznaster, R. Diniz, C. O. Fernández, M. Menacho-Márquez, A. M. Percebom, N. A. Rey, Inorg. Chem. 2019, 58, 8800-8819.

[41] A. Kostelidou, S. Kalogiannis, O.-A. Begou, F. Perdih, I. Turel, G. Psomas, Polyhedron 2016, 119, 359-370.
[42] P. R. Inamdar, R. Chauhan, J. Abraham, A. Sheela, Inorg. Chem. Commun. 2016, 67, 67-71.

[43] A. Dimitrakopoulou, C. Dendrinou-Samara, A. A. Pantazaki, M. Alexiou, E. Nordlander, D. P. Kessissoglou, J. Inorg. Biochem. 2008, 102, 618-628.

[44] M. E. Pacheco, L. Bruzzone, J. Lumin. 2013, 137, 138-142.

[45] P. Kumar, S. Gorai, M. Kumar Santra, B. Mondal, D. Manna, Dalton Trans. 2012, 41, 7573-7581.

[46] A. Bhunia, S. Mistri, R. K. Manne, M. K. Santra, S. C. Manna, Inorganica Chim. Acta 2019, 491, 25-33.

[47] D. P. Heller, C. L. Greenstock, Biophys. Chem. 1994, 50, 305-312.

[48] N. A. Rey, A. Neves, A. J. Bortoluzzi, C. T. Pich, H. Terenzi, Inorg. Chem. 2007, 46, 348-350.

[49] N. A. Rey, A. Neves, W. B. de Almeida, H. F. Dos Santos, L. A. S. Costa, Int. J. Quantum Chem. 2010, 110, 1432-1442.

[50] A. Bykowska, U. K. Komarnicka, M. Jeżowska-Bojczuk, A. Kyzioł, J. Inorg. Biochem. 2018, 181, 1-10.

[51] P. Tyagi, M. Tyagi, S. Agrawal, S. Chandra, H. Ojha, M. Pathak, Spectrochim. Acta Part A 2017, 171, 246-257.

[52] J. H. B. Nunes, R. E. F. de Paiva, A. Cuin, A. M. da Costa Ferreira, W. R. Lustri, P. P. Corbi, J. Mol. Struct. 2016, 1112, 14-20.

[53] B. Yadagiri, U. D. Holagunda, R. Bantu, L. Nagarapu, V. Guguloth, S. Polepally, N. Jain, Bioorg. Med. Chem. Lett. 2014, 24, 50415044.

[54] A. Geersing, N. Ségaud, M. G. P. van der Wijst, M. G. Rots, G. Roelfes, Inorg. Chem. 2018, 57, 7748-7756.

[55] K. Gaur, A. M. Vázquez-Salgado, G. DuranCamacho, I. Dominguez-Martinez, J. A. Benjamín-Rivera, L. Fernández-Vega, L. Carmona Sarabia, A. Cruz García, F. PérezDeliz, J. A. Méndez Román, et al., Inorganics 2018, 6, 126.

[56] A. Neves, M. A. de Brito, I. Vencato, V. Drago, K. Griesar, W. Haase, Inorg. Chem. 1996, 35, 2360-2368.

[57] L. Palatinus, G. Chapuis, J. Appl. Crystallogr. 2007, 40, 786-790. 
[58] G. Sheldrick, Acta Crystallogr. Sect. C 2015, 71, 3-8.

[59] O. V. Dolomanov, L. J. Bourhis, R. J. Gildea, J. A. K. Howard, H. Puschmann, J. Appl. Crystallogr. 2009, 42, 339-341.

[60] L. Farrugia, J. Appl. Crystallogr. 1999, 32, 837-838.

[61] P. Karsten, A. Neves, A. J. Bortoluzzi, M. Lanznaster, V. Drago, Inorg. Chem. 2002, 41, 4624-4626.

[62] A. Neves, C. N. Verani, M. A. de Brito, I. Vencato, A. Mangrich, G. Oliva, D. D. H. F. Souza, A. A. Batista, Inorganica Chim. Acta 7, 290, 207-212.

[63] R. Jovito, A. Neves, A. J. Bortoluzzi, M. Lanznaster, V. Drago, W. Haase, Inorg. Chem. Commun. 2005, 8, 323-327.

[64] V. A. Izumrudov, M. V. Zhiryakova, A. A. Goulko, Langmuir 2002, 18, 10348-10356. 


\section{Entry for the Table of Contents}

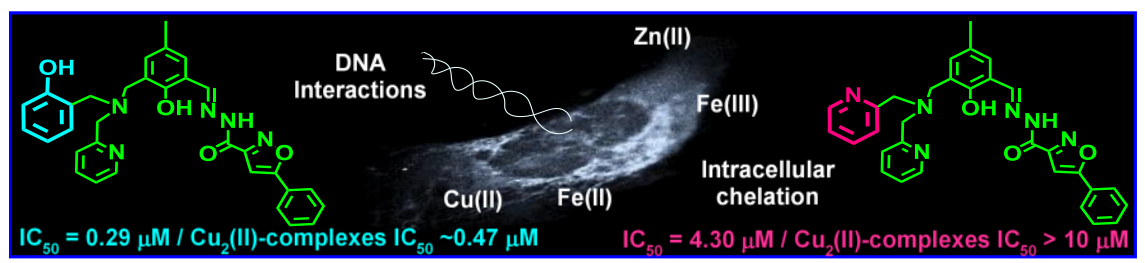

Two aroylhydrazonic ligands and their acetate/perchlorate dicopper complexes were synthesized and characterized by various spectroscopic and analytical techniques, including X-ray diffraction. They were shown to interact with DNA and display contrasted cytotoxicity on breast cancer cells. Their biological properties were linked to their ability to undergo chelation / transmetalation with biologically relevant metal ions. 